\title{
The role of type 2 Diabetes mellitus as a risk factor for Alzheimer's and Parkinson's
}

\section{diseases}

O papel do Diabetes mellitus tipo 2 como fator de risco para as Doenças de Alzheimer e Parkinson

El papel de la Diabetes mellitus tipo 2 como factor de riesgo de las Enfermedades de Alzheimer y Parkinson

Received: 01/04/2021 | Reviewed: 01/05/2021 | Accept: 01/09/2021 | Published: 01/09/2021

Kellen Mariane Athaide Rocha

ORCID: https://orcid.org/0000-0001-8038-5286

Universidade Federal do Pampa, Brazil

E-mail: kellen_a.rocha@hotmail.com

Aline da Silva Goulart

ORCID: https://orcid.org/0000-0002-3222-5816 Universidade Federal do Pampa, Brazil E-mail: alinefsgoulart@gmail.com

Márcio Tavares Costa

ORCID: https://orcid.org/0000-0003-4940-3567 Universidade Federal do Pampa, Brazil E-mail: marciocosta@unipampa.edu.br

Andréia Caroline Fernandes Salgueiro

ORCID: https://orcid.org/0000-0003-4770-2379 Universidade Federal do Pampa, Brazil E-mail: acfsalgueiro@gmail.com Vanderlei Folmer

ORCID: https://orcid.org/0000-0001-6940-9080 Universidade Federal do Pampa, Brazil

E-mail: vanderleifolmer@unipampa.edu.br

\begin{abstract}
Currently, one of the most significant health problems is the increased incidence of obesity and type 2 Diabetes mellitus (DM2). The most recent epidemiological and clinical research studies have indicated that low physical activity, as well as many genetic and environmental factors are the main causes of these metabolic disorders. It is widely recognized that insulin resistance plays a key role in the development of DM2, disrupting not only the functioning of peripheral tissues, but also the brain. Insulin plays a critical role in the central nervous system participating in neuronal survival, neuroplasticity, memory and cognitive functions. In addition, peripheral insulin resistance results in loss of brain function, which indicates a strong relationship between metabolic disorders, cognitive impairment and the emergence of neurodegenerative diseases. There are links between these different pathologies, such as increased oxidative stress, neuroinflammation, changes in glucose metabolism as well as insulin resistance. Advances in the knowledge of these links may contribute to the development of treatments for the prevention of these pathological events. Based on the above, this study aimed to review the mechanisms associated with DM2 in the development of neurodegenerative diseases, such as Alzheimer's and Parkinson's diseases.
\end{abstract}

Keywords: Neurodegeneration; Type 2 diabetes mellitus; Insulin resistance; Oxidative stress; Neuroinflammation; Hyperglycemia; Brain.

\section{Resumo}

Atualmente, um dos problemas de saúde mais significativos é o aumento da incidência de obesidade e Diabetes mellitus tipo 2 (DM2). Os estudos epidemiológicos e clínicos mais recentes indicam que a baixa atividade física, assim como muitos fatores genéticos e ambientais, são as principais causas desses distúrbios metabólicos. É amplamente reconhecido que a resistência à insulina desempenha um papel fundamental no desenvolvimento do DM2, interrompendo não apenas o funcionamento dos tecidos periféricos, mas também do cérebro. A insulina desempenha um papel crítico no sistema nervoso central, participando da sobrevivência neuronal, neuroplasticidade, memória e funções cognitivas. Além disso, a resistência periférica à insulina resulta em perda da função cerebral, o que indica uma forte relação entre distúrbios metabólicos, comprometimento cognitivo e o surgimento de doenças neurodegenerativas. Existem ligações entre essas diferentes patologias, como aumento do estresse oxidativo, neuroinflamação, alterações no metabolismo da glicose e também resistência à insulina. Avanços no conhecimento dessas ligações podem contribuir para o desenvolvimento de tratamentos para a prevenção desses eventos patológicos. 
Com base no exposto, este estudo teve como objetivo revisar os mecanismos associados ao DM2 no desenvolvimento de doenças neurodegenerativas, como Doença de Alzheimer e Doença de Parkinson.

Palavras-chave: Neurodegeneração; Diabetes mellitus tipo 2; Resistência à insulina; Estresse oxidativo; Neuroinflamação; Hiperglicemia; Cérebro.

\section{Resumen}

Actualmente, uno de los problemas de salud más importantes es el aumento de la incidencia de obesidad y Diabetes mellitus tipo 2 (DM2). Los estudios epidemiológicos y clínicos más recientes indican que la baja actividad física, así como muchos factores genéticos y ambientales, son las principales causas de estos trastornos metabólicos. Es ampliamente reconocido que la resistencia a la insulina juega un papel clave en el desarrollo de DM2, alterando no solo el funcionamiento de los tejidos periféricos, sino también el cerebro. La insulina juega un papel fundamental en el sistema nervioso central, participando en la supervivencia neuronal, neuroplasticidad, memoria y funciones cognitivas. Además, la resistencia a la insulina periférica da como resultado la pérdida de la función cerebral, lo que indica una fuerte relación entre los trastornos metabólicos, el deterioro cognitivo y la aparición de enfermedades neurodegenerativas. Existen vínculos entre estas diferentes patologías, como aumento del estrés oxidativo, neuroinflamación, cambios en el metabolismo de la glucosa y también resistencia a la insulina. Los avances en el conocimiento de estos vínculos pueden contribuir al desarrollo de tratamientos para la prevención de estos eventos patológicos. Con base en lo anterior, este estudio tuvo como objetivo revisar los mecanismos asociados a la DM2 en el desarrollo de enfermedades neurodegenerativas, como la Enfermedad de Alzheimer y Enfermedad de Parkinson.

Palabras clave: Neurodegeneración; Diabetes mellitus tipo 2; Resistencia a la insulin; Estrés oxidative; Neuroinflamación; Hiperglucemia; Cerebro.

\section{Graphical Abstract}

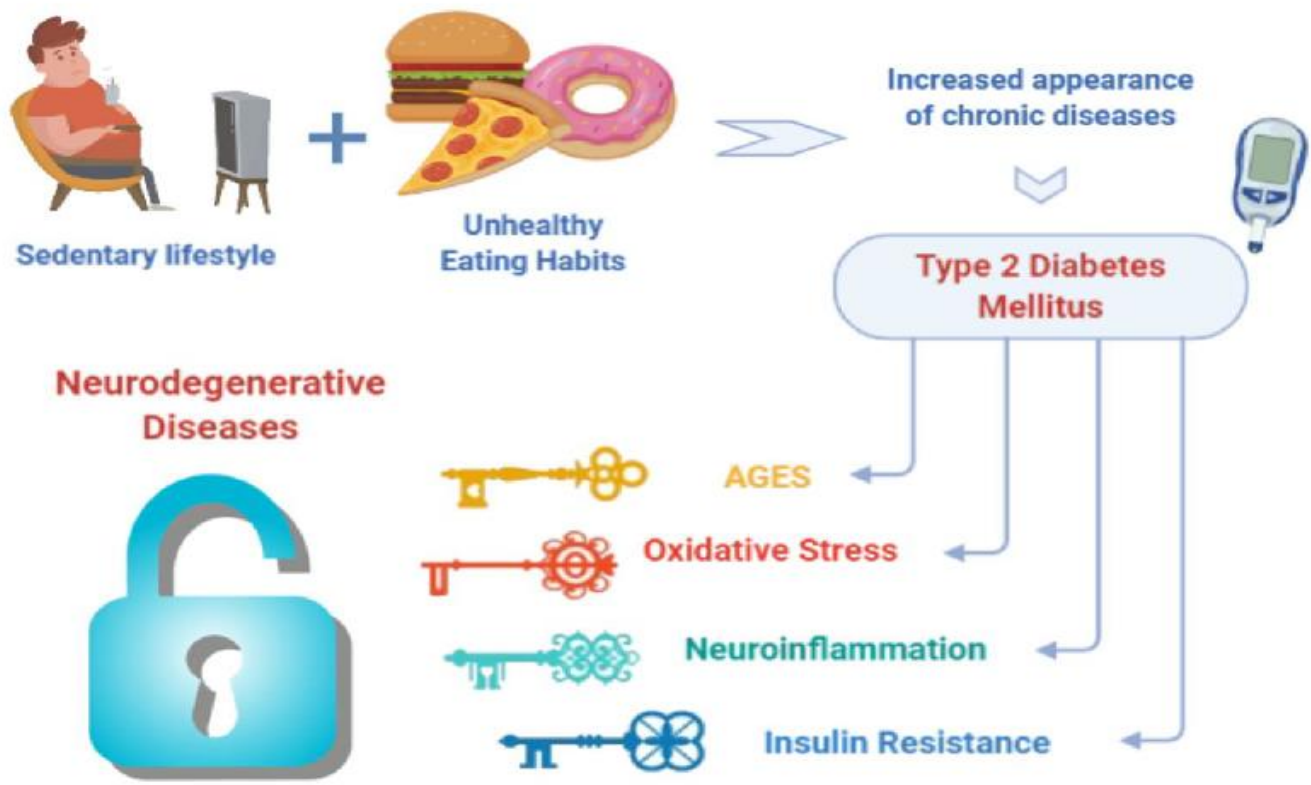

\section{Introduction}

Over the years there were changes in the lifestyle of world population due to increased consumption of industrialized products. These foods containing high levels of fat and sugars, which together with a decrease in the practice of physical exercises, contribute to emergence of chronic diseases, especially in elderly population.

In fact, as population ages, chronic diseases become a concern for health systems as well as for the economy (Prince et al., 2013). The World Health Organization (WHO) estimates that in the year 2050 the elderly population will be composed of 2 billion people, about $22 \%$ of the world population. In addition to the aging process that triggers a decline in physiological functions, the high consumption of hypercaloric foods stimulates the appearance of metabolic disorders, such as Type 2 Diabetes mellitus (DM2) (Flor \& Campos, 2017). 
DM2 has become extremely common due to obesity prevalence in elderly population. Several strategies have been developed so that patients with DM2 have a better quality of life and longer survival, however there are other complications. We highlighted that patients with DM2 develop between 50 and 150\% more neurodegenerative diseases than general population (Li et al., 2015; Schernhammer et al., 2011). Indeed, Alzheimer's (AD) and Parkinson's diseases (PD) are the most prevalent neurodegenerative diseases in the world. They affect about $2 \%$ of the world elderly population, and are characterized by cognitive decline of affected patients (Schernhammer et al., 2011). Recent studies seek to understand mechanisms, in addition to the genetic factor, that are involved in the onset, pathophysiology and progression of these diseases.

In this context, have evidences that insulin:

- Plays a very important role in the pathophysiology of DM2 (Donath \& Shoelson, 2011; Timper \& Donath, 2012);

- Has neuromodulatory and neurotrophic effects (Blázquez et al., 2014; Maciejczyk et al., 2019);

- It's involved in the neurodegeneration process (Macauley-Rambach et al., 2015; Maciejczyk et al., 2019).

Based on the above, this study aimed to review the mechanisms associated with DM2 in the development of neurodegenerative diseases, such as $\mathrm{AD}$ and $\mathrm{PD}$.

\section{Methodology}

This study is an exploratory bibliographic research with a qualitative approach and developed based on material already prepared, consisting mainly of books and scientific articles. Although the studies require some type of review, there is research developed exclusively from bibliographic sources. Thus, our exploratory study obtain the main advantage of the fact that it allows the researcher to cover a range of phenomena much wider than that which he could research directly (Gil, 2002; Pereira et al., 2018).

In this context, the main research steps occurred between October 2019 and May 2020. We highlighted that to carry out this study was consulted PubMed database for search materials using the combination of the following keywords: Parkinson AND Alzheimer AND diabetes AND "insulin resistance". There were searches based in the title, abstract and keywords of articles published from 2002 until 2020. This process resulted in a total 3061 papers in PubMed. Lastly, our filtering (Figure 1) reduced the number of articles from 3061 to 132. 
Figure 1. Flowchart showing criteria for selecting articles.

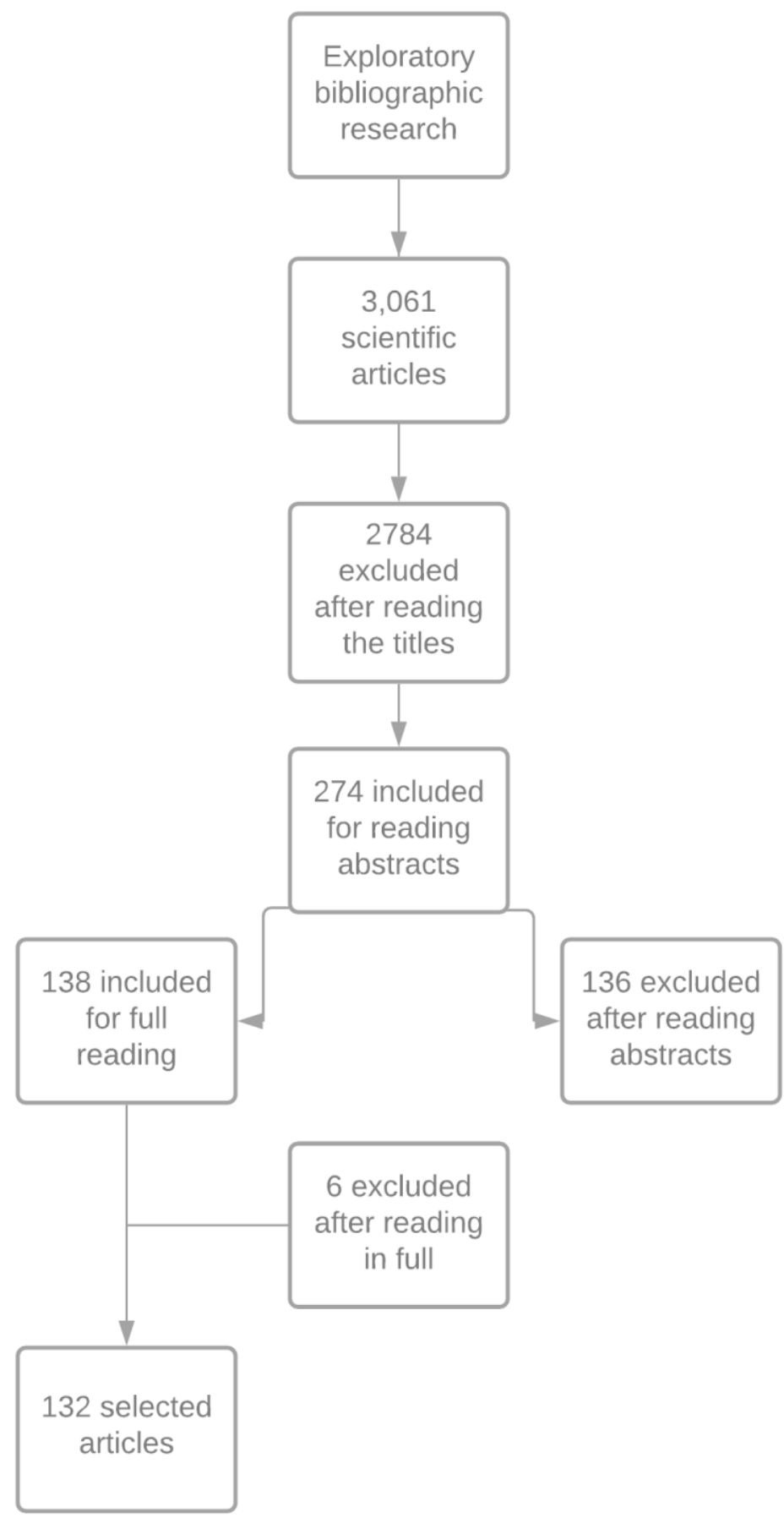

Source: Authors

\section{Type 2 Diabetes mellitus (DM2)}

DM2 covers about $90 \%$ of diagnosed DM cases in the population. Approximately $20 \%$ of individuals between 65 and 75 years old have DM (Iser et al., 2015). This metabolic disorder is characterized by a condition of hyperglycemia, in which insulin is not effective in maintaining glucose levels, caused by resistance to hormone. Among the risk factors are genetic predisposition, besides environmental factors as unhealthy eating habits and physical inactivity (Seino et al., 2010). 
The onset of DM2 usually has mild symptoms, because pancreatic $\beta$ cells produce a greater amount of insulin to compensate the hormonal resistance. However, the insulin-producing cells belatedly fail, showing hyperglycemia and making the diagnosis possible (Timper \& Donath, 2012).

Insulin resistance is a consequence of several intracellular changes that are related to numerous mechanisms resulting from obesity. First, adiposity release cytokines and produce oxidative stress. Moreover, the increase in circulating free fatty acids causes a competition with glucose, which generates a decrease in uptake by insulin-dependent tissues through the glucose transporter GLUT-4 (Donath \& Shoelson, 2011).

There is a greater secretion of insulin when glucose concentrations increase, in order to try increase the transport of this glucose to muscle and fat tissues. However, in situations like this, insulin may not bind to its receptor, therefore it does not promote the autophosphorylation of insulin receptors (IR), nor the phosphorylation of tyrosine residues. Thus, the uptake of glucose into the tissues does not occur. The progression and permanence of this condition leads to the exhaustion of pancreatic $\beta$ cells and generating irreversible damage (Atkinson et al., 2013).

In DM2 there is an increase in the production of reactive oxygen species (ROS), this can occur due to the increased flow in the polyol pathway, increased formation of advanced glycation end products (AGEs) (Salgueiro et al., 2016), activation of protein kinase C (PKC) isoforms, and increased flow of the hexosamine pathway (Brownlee, 2005; Silva et al., 2011). In fact, studies with in vitro and in vivo hyperglycemic models demonstrate that there is an increase in the production of free radicals and consequent oxidative stress in high glucose conditions (Folmer et al., 2002; Salgueiro et al., 2013; Salgueiro et al., 2016).

When the polyol pathway is activated it contributes to oxidative stress as it causes depletion of NADPH and a consequent decrease in the levels of intracellular glutathione (Pitocco et al., 2010). In addition, with the occurrence of hyperglycemia, aldose reductase reduces glucose to sorbitol, which is later oxidized to fructose. In the process of reducing the high content of intracellular glucose, aldose redutase consumes the NADPH cofactor. However, NADPH is also the essential cofactor for the regeneration of the intracellular antioxidant glutathione (Silva et al., 2011).

AGEs are mainly observed in structural proteins; However they are also commonly formed in hemoglobin, catalase and SOD proteins, altering their normal functions (Niedowicz \& Daleke, 2005). The increase in PKC activity and the AGEs formation resulting from chronic hyperglycemia are involved in the response that induces endothelial cells to enter an inflammatory state, leading to production of pro-inflammatory cytokines (Brownlee, 2005; Pitocco et al., 2010).

In DM2, there is an increase in nuclear factor kappa B (NFkB) pathway activation, due to high glucose levels. NFkB stimulates the production of cytokines, such as TNF- $\alpha$ (tumor necrosis factor alpha), IL-1, IL-6, IL-2 and IL-12. In addition to increasing the expression of molecules involved in the regulation of cell proliferation, apoptosis and cell cycle progression (Francés et al., 2013).

\section{Characterization of Neurodegenerative Diseases}

\subsection{Alzheimer}

$\mathrm{AD}$ is a chronic neurodegenerative disorder, being the most common form of dementia in the elderly, which represents 50 to $75 \%$ of all cases. It is characterized by degeneration of neurons in specific brain regions, mainly the hippocampus. Consequently, leads to a clinical picture of progressive loss of memory and impairments in cognitive functions (Choi et al., 2014).

Among the multiple causes associated with the onset of $\mathrm{AD}$, three stand out: The $\varepsilon 4$ allele of apolipoprotein $\mathrm{E}$ (apoE), one of the major risk factors for the onset of $\mathrm{AD}$ and also an important indicator of its development (Poirier et al., 2014). 
Another cause for development of this disease is the accumulation of beta-amyloid plaques, the third cause being neurodegeneration mediated by tau (Alves et al., 2012; Sun et al., 2011).

Regarding the $\varepsilon 4$ allele of apoE, in the human body this gene is located on the long arm of chromosome 19 (19q13.2). Information contained in this gene is important for the apoE protein formation, since this protein is fundamental in the mechanism of redistribution of triglycerides and cholesterol in the various tissues of human organism (Poirier et al., 2014). The second most important organ in apoE synthesis is the brain, assuming a specific role in the formation of amyloid plaques. Happens an interaction between soluble beta-amyloid $(\mathrm{A} \beta)$ and apoE, creating an apoE-A $\beta$ complex. Later it is digested enzymatically and gives rise to two portions, one is degraded and the other promotes the accumulation of amyloid plaques that will be excreted into the extracellular medium (Castellani et al., 2014; Holtzman et al., 2011).

$A \beta$ is a proteolytic fragment formed from a larger transmembrane glycoprotein, APP, which undergoes the action of the proteolytic enzymes $\beta$ - and $\gamma$-secretases. Mechanisms responsible for $\mathrm{A} \beta$ neurotoxicity are complex, but it is believed to involve breaking down intracellular calcium and potassium homeostasis, inducing oxidative stress and activating the cell death process and neuroinflammation via caspases (Nelson \& Schmitt, 2011; Reddy, 2011).

$\mathrm{A} \beta$ is the major constituent of plaques and is characterized as the major agent of $\mathrm{AD}$ pathology. Levels of amyloid precursor protein (APP) in AD are increased, which causes an extracellular increase in $\mathrm{A} \beta$ amyloid fiber plaques. Along with amyloid fibers, there are also disordered neurocellular fibers. Deposition of these amyloid plaques leads to a large decrease in neurons in the brain (Castellani et al., 2014; Reddy, 2011). Intracellular neurofibrillary tangles (NFTs) and senile plaques can be present in normally senile brains, but in lesser quantities and with less extensive distribution (Nelson \& Schmitt, 2011).

NFTs are made up primarily of tau proteins associated with microtubules (Nelson \& Schmitt, 2011). Tau proteins provide stability to the microtubules of the neural cytoskeleton, and this function is regulated by a process of phosphorylation and dephosphorylation. In neurons that undergo degeneration, the tau proteins associated with microtubules become abnormally hyperphosphorylated and accumulate in the form of paired helical tangled filaments. In turn, senile plaques consist of the deposition of amyloid fragments in the brain parenchyma (Alves et al., 2012; Holtzman et al., 2011; Nelson \& Schmitt, 2011).

Patients in the initial stage of the disease, experience initial memory loss and difficulty to understanding new events. During the development of the pathology, patients present: motor alterations, speech impairment, eating disorders, and mainly impaired memory (Araújo \& Nicoli, 2010; Montufar et al., 2017).

\subsection{Parkinson}

PD is the second most common neurodegenerative disease, affecting approximately $2 \%$ of the elderly population (Pringsheim et al., 2014). Common features of PD include neuronal loss in specific areas of the substantia nigra and widespread intracellular protein $\alpha$-synuclein ( $\alpha$-Syn) accumulation, loss of dopaminergic neurons with subsequent depigmentation and the presence of Lewy bodies (Athauda \& Foltynie, 2016; Braak et al., 2003). However, neither the loss of pigmented dopaminergic neurons in the substantia nigra nor the deposition of $\alpha$-Syn in neurons is specific for PD (Balestrino \& Schapira, 2020; Poewe et al., 2017).

Loss of dopaminergic neurons, in early PD stage, is restricted to the ventrolateral substantia nigra with relative sparing of other midbrain dopaminergic neurons, but becomes more widespread by end-stage disease. The dramatic loss of these dopaminergic neurons even early in the disease suggests that degeneration in this region starts before the onset of motor symptoms (Balestrino \& Schapira, 2020; Poewe et al., 2017).

Other characteristic is deposition of $\alpha$-Syn in cytoplasm of certain neurons in several different brain regions. Lewy bodies are which are largely made up of aggregated $\alpha$-Syn. The Lewy pathology initially occurs in cholinergic and 
monoaminergic brainstem neurons and in neurons in the olfactory system, but is also found in limbic and neocortical brain regions with disease progression (Balestrino \& Schapira, 2020; Dickson, 2018).

Motor characteristics, such as stiffness, tremors, postural instability and bradykinesia are due to loss of dopaminergic innervation in the striatum. In addition to motor characteristics, PD also presents hyposmia, cognitive impairment, depression, anxiety and even psychosis (Vicente Miranda et al., 2016).

Although AD and PD are clinically distinct, they share common resources. Studies report that there is a significant occurrence of Lewy bodies and Lewy neuritis in the brain of patients with AD. In addition, $\alpha$-Syn is present in amyloid plaques in brains with $\mathrm{AD}$ and its levels increase in cerebrospinal fluid (CSF). On the other hand, it is suggested that tau and $\mathrm{A} \beta$ play a role in PD, and the presence in CSF is used as an early diagnosis of PD (Koehler et al., 2013; Mattsson et al., 2013; Murphy \& Levine, 2010).

Genetic causes represent less than 5\% of cases. The vast majority of AD and PD cases are sporadic, suggesting that non-genetic factors may contribute to beginning and progression of these diseases. Environmental factors, such as contact with pesticides, herbicides and heavy metals, as well as diet, are considered risk factors for the development of neurodegenerative diseases (Gao et al., 2007).

Observational studies have shown that the diet composition is extremely important for the prevention or emergence of diseases such as AD and PD. In this sense, diets rich in sugars and fats are factors that compromise the normal functioning of the CNS, contributing to the development of these diseases (Compta et al., 2014; Irwin et al., 2013).

\section{The Role of Insulin in the Brain}

Insulin is a hormone that regulates glucose homeostasis throughout the body. Most IR are located in target tissues, such as liver, skeletal muscles and adipose tissue. However, its expression in the brain has also been reported, mainly in the hippocampus, hypothalamus, cerebral cortex and olfactory bulb (Cole et al., 2007; Maciejczyk et al., 2019).

The origin of insulin in the brain is not only from pancreatic $\beta$ cells, but can also be synthesized again in neurons and glial cells. However, it has a similar molecular mechanism in the brain and the periphery (Blázquez et al., 2014; Gray et al., 2014). Insulin and insulin-like growth factor (IGF) are very important signaling mechanisms in the stability of synaptic plasticity for cognitive functions in the brain (Bitel et al., 2012; Pham et al., 2013).

We know that insulin binds to IR and several tyrosine residues are activated by self-phosphorylation. These phosphoresidues are important for the insulin receptor substrate (IRS) because they activate several signaling cascades, such as phosphatidylinocytol 3-kinase (PI3K), GSK3 $\beta$, mitochondrial regulation for energy production and wnt signaling cascade. The metabolic actions of insulin are mainly associated with PI3K, protein responsible for the conversion of phosphatidylinositol 4,5 bisphosphate (PIP2) to phosphatidylinositol 3,4,5 triphosphate (PIP3) (Fisher \& White, 2004; Pardeshi et al., 2017).

In addition, PIP3 recruits protein kinase B (Akt), in which will be phosphorylated and activated by specific protein kinases. Akt has several cellular targets, such as GSK3 $\beta$ phosphorylation. This path connects IR on the cell surface with enzymes of glycogen metabolism occurs (Fisher \& White, 2004; Lizcano \& Alessi, 2002).

Insulin affects the density of neurotransmitter receptors, inhibits norepinephrine and stimulates the reuptake of serotonin in the synapses of the CNS (Maciejczyk et al., 2019). Also has the ability to regulate synaptic plasticity by internalizing neurotransmitter receptors as alpha-amino-3-hydroxy-methyl-5-4-isoxazole propionic receptors (AMPA), causing long-term depression. It is also responsible for gamma-aminobutyric acid (GABA) receptor-mediated synaptic transmission by recruiting GABA receptors to postsynaptic membranes. As well as controls the internalization of receptors $\beta$-adrenergics (Alberdi et al., 2010; Blázquez et al., 2014; Maciejczyk et al., 2019). 
Insulin also has the ability to model the concentration of neurotransmitters, such as acetylcholine and norepinephrine, which is a possible influence of insulin on cognitive function. The effects of insulin on norepinephrine were studied in an animal model study in which it was concluded that this hormone inhibits the uptake of norepinephrine (Ghasemi et al., 2013). It has also been reported that systemic administration of insulin produces an increase in the levels of dopamine and serotonin in the CSF, causing the underexpression of a2-adrenergic receptors in the hypothalamus (Blázquez et al., 2014).

In DM2, TNF- $\alpha$ signaling activates the enzyme serine kinase JNK, which acts on insulin receptor substrate 1 (IRS-1), providing phosphorylation making it inactive and blocking the action of insulin. This is supported by several studies that show high levels of IRS-1 in the hippocampus and cortex of patients with AD, as well as in patients and animal models of PD (Zhao et al., 2008).

Another factor that can influence the inactivation of IRS-1 is $\alpha$-Syn, suggesting that it is able to negatively regulate insulin signaling. However, the mechanisms underlying this process aren't still well established. These data suggest that maintaining the stability of IRS-1 may play an important role in the etiology of insulin resistance in these diseases (Athauda \& Foltynie, 2016; Duka et al., 2009).

Glucose transport in the human brain affected by AD is reduced in cerebral cortex, hippocampus and microvessels. Post-mortem investigations of the brain of AD patients showed decreased protein levels of GLUT1 and GLUT3, especially in the cerebral cortex, with significant loss of GLUT3 (Gejl et al., 2017; Szablewski, 2017).

It was also considered that insulin signaling in the CNS may be involved in the formation of declarative memory and that insufficient cerebral insulin signaling plays a critical role in the loss of memory functions associated with AD (Morita et al., 2019). Craft et al., (2003) analyzed the degree of brain sensitivity to insulin action in patients with AD and insulin resistance. Was administered endogenous insulin in these patients and verified improved memory, suggesting that insulin acts as a neuromodulator and assist to release neurotransmitters linked to memory. Moreover, it is able to stimulate glucose uptake in brain regions, such as the hippocampus, responsible for memory.

Insulin resistance in diabetic patients is characterized by an impaired ability to inhibit glucose output, leading to glucose toxicity. Decreased insulin signaling affects glucose uptake in the substantia nigra and glucose metabolism, affecting neuron function. The release of dopamine from dopaminergic neurons is affected by glucose levels and is modulated by these actions in potassium channels sensitive to ATP (K ATP) (Macauley-Rambach et al., 2015). In PD patients, insulin resistance is associated with a severe phenotype, accelerated disease progression and increased risk of cognitive decline, while in experimental models it is associated with dopaminergic degeneration, motor and cognitive deficits (Reagan, 2012).

Another factor linked to insulin resistance is the inhibition of the phosphorylation process of IRS-1, by JNK, reducing the expression of IDE, which concomitant with the greater secretion of TNF- $\alpha$ generates the accumulation of NFTs. This whole process promotes the phosphorylation of the tau protein, through the activity of glycogen synthase kinase-3 (GSK-3), interfering in the development of neuronal cells, impairing synaptic plasticity, cognitive capacity and memory (Pardeshi et al., 2017). The cerebral insulin/IGF resistance leads to increased activation of GSK-3 $\beta$. It was shown that stimulation of GSK-3 $\beta$ promotes hyperphosphorylation of tau protein, and therefore induces tau misfolding and fibril aggregation in the brain (Maciejczyk et al., 2019; Tumminia et al., 2018).

The condition of hyperinsulinemia present in DM2 impairs the degradation of A $\beta$, since the same enzyme (IDE) that degrades it also degrades insulin, having greater affinity for the latter, thus generating an accumulation of $\mathrm{A} \beta$ in the brain (Gudala et al., 2013). This evidence suggests that insulin resistance is a cellular link between DM2 and neurodegenerative diseases (Figure 2). 
Figure 2. Neurodegeneration pathways associated with DM2.

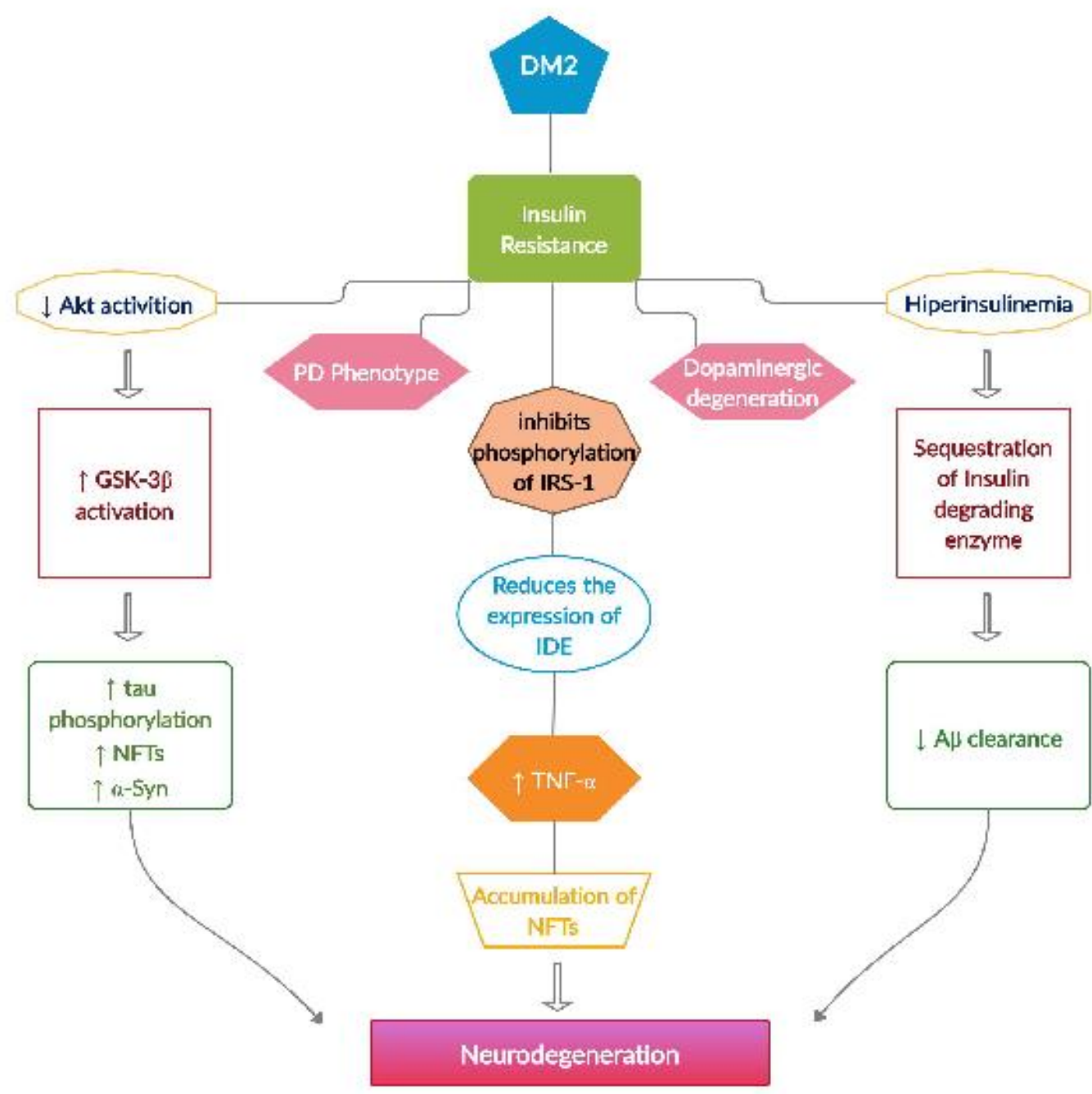

Source: Authors

These characteristics lead us to believe that insulin is not only involved in glucose metabolism for neuronal survival, but also in the regulation of synaptic transmission to establish synaptic plasticity. Therefore, it is extremely important to investigate whether DM2 is associated with abnormal neuronal function.

\section{Advanced Glycation end Products (AGEs) in AD and PD}

AGEs are molecules formed by Maillard reaction (non-enzymatic glycation of amino group of proteins). These molecules are accumulated with aging and are found in both types of diabetes. The formation of these molecules in diabetes occurs due to hyperglycemia, which usually generate many complications that are initiated or potentiated by the accumulation of specific AGEs forms and their interaction with RAGE receptors (Kandimalla et al., 2017; Sato et al., 2006).

Glycation is involved with $\mathrm{pH}$, temperature and protein half-life, besides glycation agents. It is noteworthy that the proteins involved in neurodegeneration processes have a long half-life and, because this, are preferred targets for glycation. 
Proteins associated with PD and AD share this resource and have already been reported as targets for glycation (Koehler et al., 2013).

Hyperglycemia directly increases methylglyoxal (MGO) levels, a potent glycation agent. MGO plays an important role in both $\mathrm{AD}$ and $\mathrm{PD}$, increasing the formation of toxic oligomeric and aggregated forms of $\alpha$-Syn and $\mathrm{A} \beta$ (Figure 3 ). In addition, by increasing the phosphorylation of tau, it promotes the formation of neurofibrillary tangles of tau. The glycated species activate RAGE, consequently inducing an extensive inflammatory response. Thus, glycation contributes to neurodegeneration in both AD and PD (Vicente Miranda et al., 2016).

Figure 3. AGEs contribute to neurodegeneration in $\mathrm{AD}$ and $\mathrm{PD}$ and can be a link between DM2.

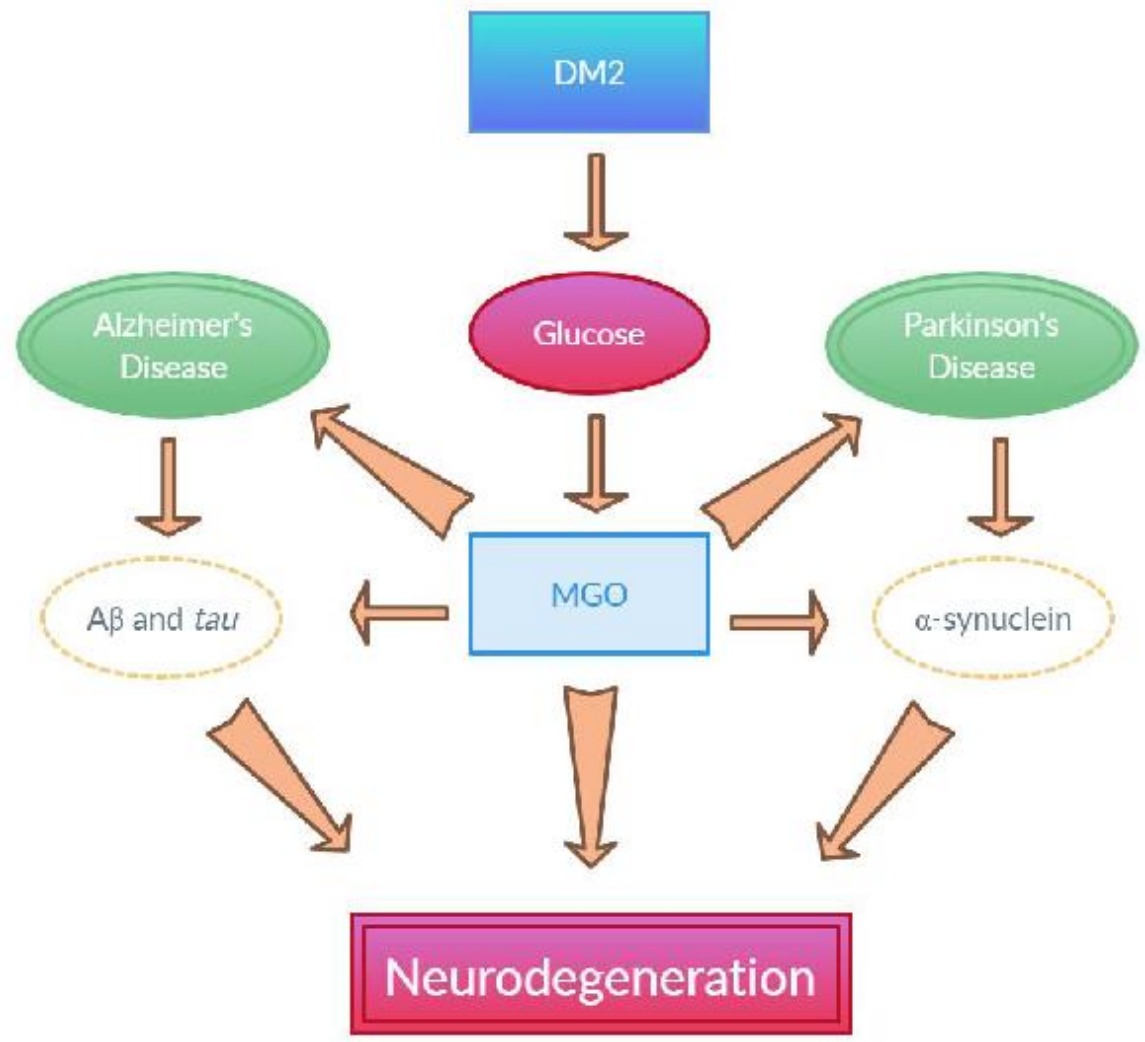

Source: Adapted from Vicente Miranda et al. (2016).

A direct consequence of hyperglycemia is the increased formation of glycation agents. A high glycemic index induces an increase of 34 times in AGEs in the brain (Vicente Miranda et al., 2016). Studies showed that glycation occurs in proteins that are directly involved in $\mathrm{AD}$, such as $\mathrm{A} \beta$ and tau (Chen et al., 2006; Woltjer et al., 2003). Furthermore, findings in the brains of patients with AD, confirm that they contained 3 times more AGEs in senile plaques and NFTs (Faure et al., 2005; Vicente Miranda et al., 2016). These data suggest that glycation promotes the formation of A $\beta$ and tau aggregates.

In $\mathrm{AD}$, glycation not only plays a role in the formation of protein aggregates, but also regulates the expression of APP, thus increasing A $\beta$ 1-42 levels, as well as directly modulating the increase in tau phosphorylation (Ko et al., 2010). In addition, the levels of glycated proteins are increased in CSF in patients with AD, which may become a biomarker for this disease (Vicente Miranda et al., 2016).

In order to clarify the role of glycation on $A \beta$, was assessed the toxicity of normal and glycated $A \beta$ on primary hippocampal neurons. The authors of this assessment confirmed the hypothesis that glycation increases A $\beta$ toxicity. Therefore, 
glycation may be responsible for increasing the binding of these proteins and consequently the formation of stable oligomeric forms (Wang et al., 2010).

There is an increase of protein glycation in both diseases, AD and PD. AGEs have been found in cerebral cortex, amygdala, substantia nigra and periphery of Lewy bodies, as well as newly formed Lewy bodies of patients with PD. This suggest that they could encourage the formation of Lewy bodies in patients considered pre-PD (Y. G. Choi \& Lim, 2010; Dalfó et al., 2005).

AGEs also have been found in dopaminergic neurons, as well as in oligomeric species of $\alpha$-Syn in animal models of parkinsonism. There are reports that glycation has the ability to accelerate $\alpha$-Syn aggregation through cross-link induction and formation of $\alpha$-Syn oligomers. However, the role that glycation plays on PD is still unclear (Y. G. Choi \& Lim, 2010; Lee et al., 2009).

Diets rich in fats are used to mimic this phenomenon in animal models, showing they are capable of increasing the depletion of dopaminergic neurons. In addition, it accelerates the onset of locomotor impairment and promotes $\alpha$ synucleinopathy in the brain of genetically modified mice. However, further studies are needed to elucidate the effects of diets on PD progression (Morris et al., 2010). These findings highlight the importance of glycation in the context of AD and PD and suggest that inhibition of protein glycation may be a potential target for therapeutic interventions in these diseases.

\section{The Involvement of Oxidative Stress in DM2, AD and PD}

Excessive glucose generates the production of NADH (nicotinamine adenine dinucleotide reduced) exacerbated, as well as promoting the oxidation of low-density lipoproteins via an $\mathrm{O}^{2}$-dependent pathway, resulting in a cascade of free radicals generation. The oxidative reaction is a fundamental process that occurs in aerobic metabolism of each mammalian cell. These reactions are essential for life, however, if unregulated they can become harmful to the organism, as already seen in several processes of different diseases (Kandimalla et al., 2017).

Oxidative stress occurs when there is an imbalance between ROS and reactive nitrogen species (RNS) production and the inability of antioxidant compounds to neutralize them. These reactive species are formed by breaking a covalent bond between two atoms or through oxy-reduction reactions, resulting in atoms with an unpaired electron in the last valence layer (Gottlieb, 2010).

These formed atoms are unstable and reactive molecules, interacting with other molecules in order to reintegrate an electron and with this action causes them to undergo oxidation (Giacco \& Brownlee, 2010). As soon as these reactive species are formed, antioxidants act in order to prevent possible injuries generated. However, when antioxidants are not able to combat oxidative damage caused by oxidative species, the body suffers from oxidative stress (Cobb \& Cole, 2015).

Aerobic cellular respiration uses glucose and oxygen to produce energy and is one of the main physiological sources of reactive species production. Among the free radicals, the superoxide anion $\left(\mathrm{O}^{2} \bullet-\right)$ and hydroxyl radicals $(\mathrm{OH} \bullet)$ stand out. Among the non-radical species stand out hydrogen peroxide $\left(\mathrm{H}^{2} \mathrm{O}^{2}\right)$ and hypochlorous acid ( $\left.\mathrm{HOCl}\right)$. The latter do not have electronic mismatches, however, due to their high instability, they are classified as reactive species (Baglietto-Vargas et al., 2016; Radi et al., 2014).

The high production of ROS and RNS induce the phosphorylation of IRS proteins (insulin receptor substrate), through the activation of serine kinases. Above all, the $\mathrm{kB}$ necrosis factor inhibitor kinase (IKkB) is activated by the reactive species, phosphorylating serine residues from the insulin signaling chain. These processes impair insulin signaling, generating resistance to this hormone. For this reason, muscle and fat cells induce resistance to the action of insulin in an attempt to contain glucose intake, which is a defense mechanism against oxidative stress (Giacco \& Brownlee, 2010). 
Due to damage caused by oxidative stress, cellular machinery is prepared with powerful antioxidant systems that capture, neutralize and even prevent ROS formation. In addition, they are also able to repair already damaged structures. Antioxidants are defined by three lines of defense, whether they are exogenous or endogenous (Barbosa et al., 2006; Nowotny et al., 2015).

In the first line, are vitamins $\mathrm{C}$ and $\mathrm{E}$, carotenoids, flavonoids and glutathione (GSH), the latter being the most important and most abundant cellular antioxidant (Barbosa et al., 2006). The second line is enzymatic antioxidants, responsible for converting highly reactive species into less reactive molecules. Enzymes superoxide dismutase (SOD) and catalase (CAT) are the most important. Finally, the third line is composed of proteasomes, proteases, lipases, DNAses and RNAses (Nowotny et al., 2015; Pisoschi \& Pop, 2015).

Hyperglycemia promotes the overactivation of the three cellular energy production pathways. The hyper-stimulation of glycolysis and the Krebs cycle, will result in the exacerbated production of reduced flavin adenine dinucleotide (FADH2) and NADH, supercharging the Electron Transport Chain, which is a source of ROS generation. Stimulation of hyperpolarized mitochondria with a high redox potential produces more adenosine triphosphate (ATP) and releases higher levels of $\mathrm{O}^{2}-\bullet \cdot \mathrm{O}^{2}-$ - will give rise to the other types of ROS and RNS (Ahmad et al., 2017; Amorim et al., 2019).

The CNS does not have a powerful antioxidant system and requires high oxygen consumption, in addition to have lipid components that can contribute to lipid peroxidation. All of these characteristics favor the CNS to be prone to damage resulting from reactive species (Figure 4). Like aging, DM2, through hyperglycemia, exacerbates the effects of free radicals on the brain, which is one of the factors in the pathogenesis of neurodegenerative diseases (Sims-robinson et al., 2011).

Figure 4. Characteristics that favor the brain to be prone to damage resulting from reactive species.

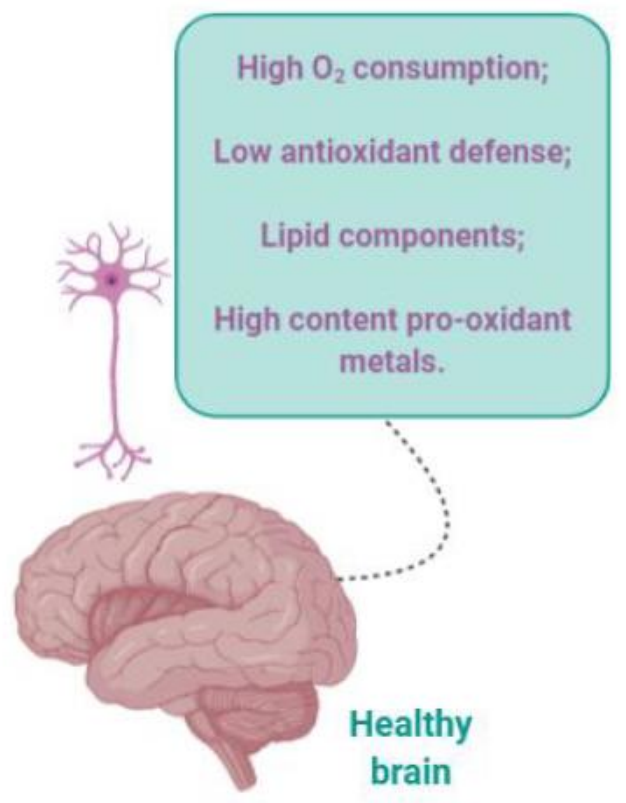

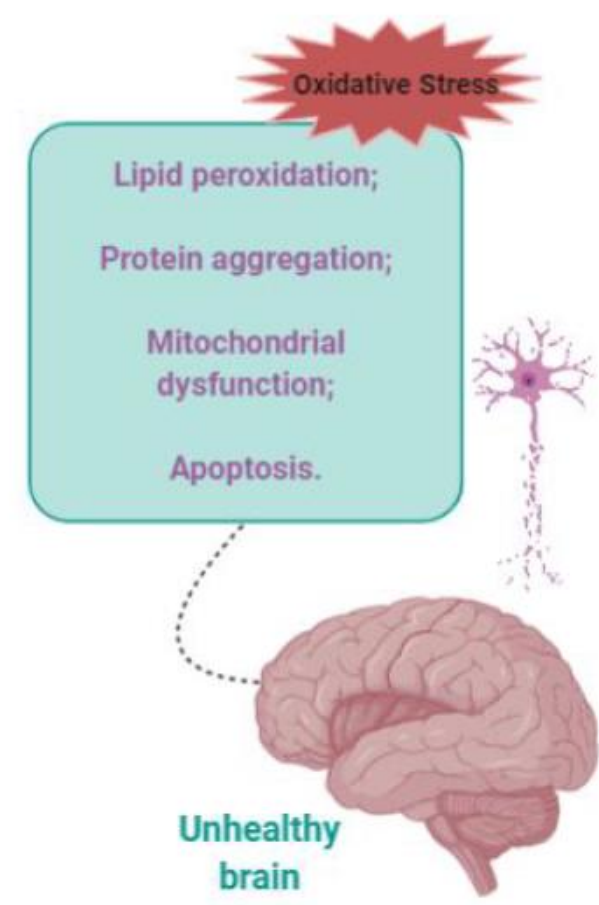

Source: Adapted from de Maciejczyk et al. (2019). 
Several hypotheses have described oxidative stress as the main factor in the pathophysiology of neurodegenerative diseases. In PD, oxidative stress causes damage to substantia nigra, due to its highly susceptible to contain a high population of dopaminergic neurons that produces significant amounts of ROS. In addition, being post-mitotic, neurons in the brain, once damaged, may be permanently dysfunctional (Tsang \& Chung, 2009; Tuon, 2012).

Although the nature of the neurodegenerative process seen in PD is not known, the involvement of the high oxidative potential of dopamine in $\mathrm{H}^{2} \mathrm{O}^{2}$ generation and other ROS has been suggested, as well as the high concentration of iron and its altered homeostasis, and low levels of glutathione (Barbosa et al., 2006; Perfeito et al., 2012; Tsang \& Chung, 2009; Tuon, 2012). Another characteristic of PD is the accumulation of iron in the substantia nigra (Perfeito et al., 2012). Previous studies in individuals with PD have identified an increase in iron concentration in post-mortem examinations, and animal models of the disease induce iron accumulation. This evidence indicates that there is a direct relationship between iron and PD (He et al., 2003; Mochizuki \& Yasuda, 2012).

Free radicals, when they affect the $\alpha$-Syn protein, cause a change in its conformation that prevents it from being degraded, generating accumulation of aggregates and being the main component of Lewy corpuscles (Tsang \& Chung, 2009). In addition, undegraded $\alpha$-Syn is possibly exociated to prevent further intracellular damage, but ends up causing an inflammatory reaction in the extracellular environment, causing the body to produce more free radicals (Schildknecht et al., 2013).

In $\mathrm{AD}$, decline in synaptic activities, low energy metabolism and increase amount of ROS, reduced levels of antioxidant enzymes in the frontal and temporal cortex, and presence of $A \beta$ and NFTs together lead to mitochondrial dysfunction and neuronal cell death (Ahmad et al., 2017; De Felice \& Ferreira, 2014). The production of free radicals is closely associated with the disease pathology in patients with $\mathrm{AD}$. It has been shown that $\mathrm{A} \beta$ produces $\mathrm{H}^{2} \mathrm{O}^{2}$ and releasing substances reactive to thiobarbituric acid (TBARS) associated mainly with $\mathrm{OH} \bullet$ via reduction of metal ions. $\mathrm{A} \beta$ also induces neurodegeneration targeting microglial NADPH oxidase, however, the mechanism behind this destruction is poorly understood (Ahmad et al., 2017).

Elevated levels of $A \beta_{1-40}$ and $A \beta_{1-42}$ have been reported to be associated with increased levels of protein, lipid and nucleic acid oxidation products in AD hippocampus and cortex (Cheignon et al., 2018). Mitochondrial dysfunction was also involved in the pathogenesis of AD, through mitochondrial generation of ROS (De Felice \& Ferreira, 2014).

The tau protein is also a target for oxidative stress in AD. 4-hydroxinonenal (4-HNE) is capable of inducing changes in the conformation of the tau protein, favoring the formation of NFTs (Cheignon et al., 2018; Hardas et al., 2013). It is also worth mentioning that the apoE genotype, the main cholesterol-carrying protein in the brain, affects oxidative stress, since the plasma of AD apo\&4 carriers was more oxidized than the plasma of non-apos4 AD carriers (Cheignon et al., 2018; Chico et al., 2013).

\section{Neuroinflammation Associated with the Pathophysiology of DM2, AD and PD}

Insulin resistance present in DM2 generates mitochondrial dysfunction and consequently stimulates the inflammatory process. For a long time, this process was associated only with responses to injuries, such as tissue repair and defense against infections. Today, inflammation is considered an important factor in the pathogenesis of diseases such as AD and PD (Rees et al., 2011).

In DM2, the inflammatory process is triggered by an increase in the secretion of adipokines, especially TNF- $\alpha$ and IL6 (Francés et al., 2013). With the increase of these adipokines, there is an inhibition of adiponectins, which are proteins that act to assist the uptake of circulating glucose and oxidation of fatty acids in the muscles (Letra et al., 2014; Perrotta et al., 2019). They are also responsible for inhibiting TNF- $\alpha$ secretion. Therefore, in diabetic patients who have increased adiposity, 
adiponectins are reduced, demonstrating their correlation with insulin resistance, as well as with hyperglycemia (Balsan et al., 2015).

IL-6 is a pro-inflammatory cytokine secreted in response to increased liver visceral fat, responsible for increasing production of C-reactive protein (CRP) in this tissue. TNF- $\alpha$ is involved in chronic inflammation process, as well as stimulating IL-6 production through nuclear transcription factor kappa B (NF-kB) activation. In this sense, obesity is a risk factor for DM2 development, since with the increase in adiposity there is a greater secretion of pro-inflammatory cytokines, which act in insulin resistance process (Calle \& Fernandez, 2012; Kang et al., 2016).

In $\mathrm{AD}$ and $\mathrm{PD}$, neuroinflammation is an initial event in the development of these diseases due to neurodegenerative process. Microglia cells are recruited in response to inflammatory process and have a similar function to macrophages, being the main CNS defense system. These cells migrate to deposition sites of substances such as A $\beta$, and in response they secrete pro-inflammatory cytokines such as IL-6, TNF- $\alpha$, Interferon- $\gamma$, CRP, in addition to ROS and RNS (Mandrekar-Colucci \& Landreth, 2012; Tumminia et al., 2018).

Although microglial activation may initially be a protective system, prolonged activation is severely harmful since cytokines secreted in response to inflammation induce increased rates of apoptosis, as well as neuronal death. Thus, impairing synaptic function (Sekiyama et al., 2012). In addition, TNF- $\alpha$ and Interferon- $\gamma$ have neurotoxic effects on the CNS. They impair $A \beta$ degradation by the IDE, promoting senile plaques deposition (Mandrekar-Colucci \& Landreth, 2012).

Another factor that highlights the neurotoxic effect of TNF- $\alpha$ is the ability to make the blood-brain barrier more permeable by suppressing the expression of tight junction proteins (JA), exposing the CNS to pro-inflammatory cytokines (De Felice \& Ferreira, 2014) (Figure 5). Studies have shown that use of non-steroidal anti-inflammatory drugs (NSAIDs) decreased the risk of developing AD and PD (Côté et al., 2012; Rees et al., 2011).

Figure 5. In DM2, the inflammatory process is triggered by an increase in the secretion of adipokines, especially TNF- $\alpha$ and IL-6.

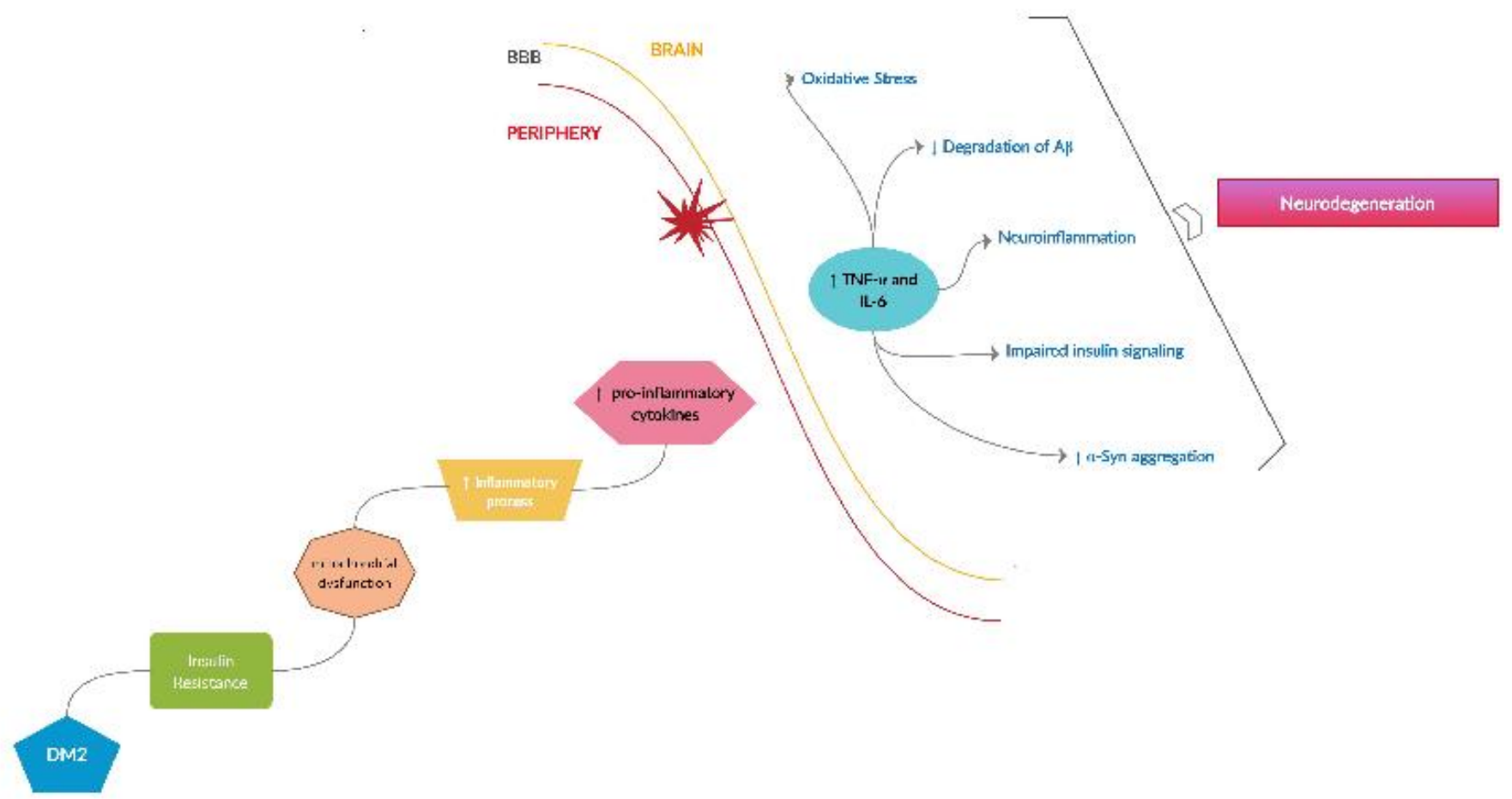

Source: Authors 
A recent study demonstrated that positive regulation of the Akt pathway, a specific endogenous inhibitor of NF-kB, results in reduced neuroinflammation. That suggests a possible link between insulin signaling and neuroinflammation (Khasnavis et al., 2012). Insulin resistance, as previously mentioned, is associated with AGEs formation, and the interaction of its RAGE receptor triggers multiple intracellular signaling pathways, including NF-kB activation, which consequently leads to increased oxidative stress, inflammation and neuronal death, as well as it is associated with increased $\alpha$-Syn aggregation and formation of Lewy Bodies in PD patients (Dalfó et al., 2005; J. Li et al., 2012).

Apparently, insulin resistance and inflammation have a reciprocal relationship, since insulin resistance can induce the production of pro-inflammatory cytokines that lead to cell death and further reduce insulin sensitization by inhibiting its receptor. Simultaneously, inflammation induces mitochondrial dysfunction, resulting in an exacerbated ROS production and providing an increase in neurodegenerative process (Dineley et al., 2014).

\section{Experimental Models}

Experimental models in research can be defined as a means of materializing a part of reality. Development of experimental models becomes important as they help in the understanding of natural phenomena, allowing greater knowledge of physiology, etiopathogenesis of diseases, action of medicines and even surgical interventions (Ferreira \& Ferreira, 2003; Hochman et al., 2004).

Animal models can be used in all fields of biological research. In the case of experimental models, it is important to conceptualize animal disease, which is one whose pathological mechanisms are sufficiently similar to human diseases, thus acting as a model. This animal model must necessarily allow the assessment of natural biological phenomena, induced or behavioral, that can be compared to human phenomena (Ferreira et al., 2005).

Due to complex interaction between genetic susceptibility and environmental factors, the pathogenesis of diabetes is often difficult and poorly understood in humans. In addition, clinical studies in diabetic patients are often unfeasible for ethical reasons, making animal models extremely useful and advantageous for biomedical research (Ribeiro Cesaretti \& Kohlmann, 2006). Since the literature has brought DM2 as a possible factor for the emergence of neurodegenerative diseases, using the models of induction of DM2 to assess the relationship of diabetes with the appearance of neurological changes is an interesting proposal.

\subsection{Type 2 Diabetes mellitus models}

Models of DM2 induction in animals can be basically divided into 3 groups: spontaneously induced models (usually genetically modified), diet induced models and chemically induced models (Srinivasan \& Ramarao, 2012).

\subsubsection{Spontaneously induced}

Spontaneously induced models may be due to monogenic or polygenic changes in chromosomes involved with the production of anorexigenic or orexigenic peptides, or the production of transgenic models and / or knockout of candidate genes (Ribeiro Cesaretti \& Kohlmann, 2006). Examples of this are the ob / ob mice, which helped to clarify the mechanism of leptin action and the insulin resistance associated with its dysfunction. This occurs through a mutation of chromosome 6 that encodes the leptin synthesis gene, the gene ob (Marques-Lopes et al., 2004). Other models that fit this category are $\mathrm{db} / \mathrm{db}$ mice and Zuker rats (fa / fa), because through their use it can be shown that mutations in the gene that determines leptin receptor synthesis also determined insulin resistance in animals (Münzberg \& Myers, 2005).

In addition to these models, transgenic animals or knockouts are also used. Among the most used are the knockouts of insulin receptors in pancreas $\beta$ cells, which showed the counter-regulatory role of insulin secretion mediated by insulin itself. 
Another example are mice deleting the intracellular signaling complexes IRS-1, IRS-2 and IRS-3, which highlighted the role of IRS-1 in mediating the physiological effects of insulin on skeletal muscle and IRS-2 on liver, muscle, adipose tissue, reproductive system and pancreatic $\beta$ cells (Nandi et al., 2004).

\subsubsection{Induced by diets}

Animals used in research are kept in laboratory under strictly controlled conditions, consuming a controlled diet and kept free of pathogens and germs. However, the fact that laboratory animals also spontaneously become diabetic, feeding on commercial feed, it opened new horizons for research in this area. Diets high in carbohydrates or lipids, in addition to a cafeteria diet, have been used to develop obesity and insulin resistance in animals. These experimental models were developed in order to clarify the effects of modern lifestyle and food on metabolism (Srinivasan \& Ramarao, 2012).

Rodent models have proven to be invaluable in supporting basic knowledge about human diseases. In the fields of obesity and DM2, rodents proved to be of great value in the basic science of diseases, identifying the role of inflammation, insulin resistance, fat content of the diet, exercise and potential treatments. This physiological similarity between the two species is due to genetic homology. Learning as a result of using these models was transferred to human patients (Heydemann, 2016).

Sand rats remain normal when in their normal habitat, but develop obesity and diabetes when fed high-calorie diets. This model can develop obesity, hyperinsulinemia, glucose intolerance leading to a picture of degeneration and necrosis of pancreatic $\beta$ cells, resulting in profound insulin deficiency and evident diabetes, which can lead to death (Srinivasan \& Ramarao, 2012).

Healthy mice of C57B1/6 strain become obese when fed high-fat diets, in addition to presenting hyperglycemia, hyperinsulinemia and hyperlipidemia. They also develop peripheral resistance to leptin and manifest most of the characteristics of patients with a genetic predisposition for the development of DM2 when they become obese (Ribeiro Cesaretti \& Kohlmann, 2006; Srinivasan \& Ramarao, 2012).

According to White et al., (2013) research, in which a model of obesity induced over a 10-week period using high-fat diets with $60 \%$ lipids was used, there was an association between obesity and insulin resistance, glucose intolerance and hyperglycemia. In protocols that use rodents, the lineage of the animal must be taken into account, as it is known that isogenic strains (C57BL/6, C57BL/6J, AKR/J, A/J) are the most conducive to obesity development due to its genetic uniformity (Heydemann, 2016).

However, when using this type of induction model, some factors must be taken into account, such as the variability in the composition of the fat and sugar used, the diet offer, whether made intermittently or continuously. Other important aspects are the protocol induction time and the individual consumption of each animal. Another factor to be taken into account is the difference in response between genders and also the animals age (Baker et al., 2017; Heydemann, 2016).

These genetic predispositions for the development of obesity and diabetes through diets with high energy density serve as more realistic and appropriate models for the study of human DM2 than the alteration of a single gene. Through the use of models like these, it was possible to broaden the knowledge about several factors that contribute to DM2 development, and the endocrine and metabolic consequences of this syndrome.

\subsubsection{Chemically induced}

Chemically induced diabetes in animals has been widely used as an experimental model to study the complications caused by diabetes. Several chemical agents are cytotoxic to beta cells in the pancreas, but treatments with alloxane and streptozotocin (STZ) are the most used to induce diabetic complications in vertebrates (Álvarez-Rendón et al., 2018; 
Arulmozhi et al., 2004). Both chemicals are toxic analogues of glucose transported to cells via Glut 2 transporter. Both treatments lead to insulin-producing cells necrosis, but by different mechanisms (Álvarez-Rendón et al., 2018).

Alloxane is a pyrimidine with a structure similar to uric acid and glucose. Scientific literature on alloxane as a diabetogenic agent is extensively revised (Carvalho et al., 2003). The site of its diabetogenic action is the beta cell of the pancreas, the binding of this substance being very fast, generating toxic free radicals, leading to cell death by necrosis (Álvarez-Rendón et al., 2018; Rohilla \& Ali, 2012).

STZ is synthesized by the yeast Streptomycetes achromogenes and was initially identified as antimicrobial, however, preclinical studies revealed that its administration in high doses caused the destruction of $\beta$-pancreatic cells (Delfino et al., 2002; Furman, 2015). STZ is cleaved, generating free methylnitrosourea which induces DNA fragmentation and deterioration of necrotic cells. Although STZ can also have toxic effects on other organs, its effectiveness and side effects depend mainly on tissue-specific Glut 2 expression, animal age and nutritional status (Álvarez-Rendón et al., 2018).

Induction of DM2 by STZ is a well-documented experimental model (Szablewski, 2017) and, in addition to hyperglycemia, treated animals develop most diabetic complications mediated by oxidative stress, such as neuropathy and diabetic retinopathy (Comelli et al., 2009), and others, such as loss of body mass (Ramkumar et al., 2011; Wang et al., 2010) and dyslipidemia (Damasceno et al., 2004). Alloxane is less used than STZ, due to the difficulties shown by some research groups in inducing diabetes and keeping animals in good condition.

\subsection{Complementary experimental models}

Most experimental tests are carried out on rodents. However, in the scientific community there is a search to decrease the use of mammals in research, making complementary experimental models more targeted (Prado et al., 2020). In this sense, to study insulin signaling and metabolic pathways relevant to human diseases such as DM2, the Drosophila melanogaster fly, popularly known as the fruit fly, can be used as an experimental model (Alfa \& Kim, 2016). This use is justified by the similarity between D. melanogaster neuroendocrine system and mammalian neuroendocrine system (S. N. S. Morris et al., 2012).

Circulating glucose levels in Drosophila are under the control of insulin-like peptides (ILPs) and the glucagon-like peptide adipokinetic hormone (AKH). Insulin-producing cells (IPCs) in adult flies synthesize three ILPs (Ilp2, Ilp3 and Ilp5), and the genetic exclusion of Ilp2 causes hyperglycemia (Alfa \& Kim, 2016). In addition, they also have seven insulin-like peptides, known as DILPS, with DILP2 being the closest to insulin in humans (Alfa \& Kim, 2016; Prado et al., 2020). Several manipulations can lead to DM2: mutations in the insulin pathway components downstream from the ILPs, dietary manipulations leading to obesity, metabolic imbalance, and hyperglycemia (Álvarez-Rendón et al., 2018).

Mutant flies homozygous for genes in the insulin pathway are born diabetic. There are advantages to this approach: the nature of the defect is known and the genetic context and environmental conditions can be strictly controlled. Defective insulin signaling due to mutations can be used to explore genes that regulate insulin secretion and also DM2, with loss-offunction mutations in the signaling pathway, in which it generates insulin resistance (Álvarez-Rendón et al., 2018).

Drosophila that are heterozygous for the mutant $\operatorname{InR}$ allele $\operatorname{InR}^{05545}\left(\operatorname{InR}^{05545} / \operatorname{InR}^{+}\right)$exhibit reduced $\operatorname{InR}$ activity but otherwise have normal circulating carbohydrates (Alfa \& Kim, 2016; Park et al., 2014). Although ILP production is unchanged in these flies, circulating ILP levels are elevated, indicating an isolated increase in ILP secretion. Targeted reduction of InR transcript in the fat body alone is sufficient to recapitulate these phenotypes (Park et al., 2014). However, whether compensatory ILP secretion in this context is mediated by a fat-body-derived signal or an increase in glucose-stimulated secretion from the IPCs secondary to the reduction in glucose disposal by the fat body remains unknown (Alfa \& Kim, 2016). 
Providing diets for Drosophila with an increase or decrease in nutrients causes the metabolism and insulin signaling to be deregulated (Álvarez-Rendón et al., 2018). Insulin resistance in Drosophila can be generated by the creation of flies on a high sugar diet (HSD) (S. N. S. Morris et al., 2012) or a high fat diet (HFD) (Birse et al., 2010). HSD causes ILP-compensated insulin resistance. However, after sustained HSD, ILP expression decreases and these flies develop hyperglycemia-like condition (Alfa \& Kim, 2016; S. N. S. Morris et al., 2012). When flies are overfed, the fat body secondarily reduces its response to insulin to the increase in circulating ILPs, and this decrease decreases significantly over time, making flies completely resistant at advanced ages (Álvarez-Rendón et al., 2018).

In addition to DM models using the fruit fly Drosophila melanogaster, another invertebrate model widely used in experiments is the nematode Caenorhabditis elegans. In this nematode, genes of insulin pathway were discovered due to their control of the formation and longevity of the dauer larva, showing a relationship between aging / nutrition / life expectancy. The insulin receptor homolog is daf-2, the IRS homolog is ist-1, the PI3K catalytic subunit is age-1, and the regulatory subunit is aap-1 (Álvarez-Rendón et al., 2018; Wolkow et al., 2002).

Experimental models in which the genetic strains are homogeneous and the environment is properly controlled, are of extreme value for the knowledge of diseases of multifactorial causes. However, even if there are different models for DM2 induction in animals, some error or inadequate choice at this stage of the research can lead to an inadequate interpretation of the data and even erroneous conclusions.

\section{Conclusion}

It is known that DM2 is characterized by chronic inflammation and insulin resistance, associated with an increase in oxidative stress. Just as it is known that these factors are also associated with the processes of neurodegeneration, as occurs in $\mathrm{AD}$ and PD. Because the incidence of DM2 continues to increase and its multifactorial etiology is still a target for debate, current studies aim to try to better elucidate the correlation among these multiple factors.

As previously discussed, insulin is responsible for glucose metabolism and its uptake. However, it also acts as a neuromodulator, helping to release neurotransmitters. Resistance to this hormone in diabetic patients is characterized by an impaired ability to inhibit glucose output, affecting neuronal function and survival as well as the stability of synaptic plasticity.

Insulin resistance can also induce the production of proinflammatory cytokines that lead to cell death and also reduce insulin sensitization by inhibiting its receptor. Consequently, inflammation induces mitochondrial dysfunction, resulting in exacerbated ROS production. Another factor associated with insulin resistance is the association in AGEs formation and the interaction of its RAGE receptor. Triggering multiple intracellular signaling pathways that lead to increased oxidative stress, inflammation and neuronal death, providing an increase in the neurodegenerative process.

These data lead us to believe that insulin, or resistance to this hormone, has a central role as a key factor that links these different pathologies. Because through it, other factors such as increased oxidative stress, increased production of AGEs and exacerbated inflammation are triggered, favoring the emergence of events related to the process of neurodegeneration. Bringing light to the connection between DM2 and neurodegenerative diseases.

In the previous sections, we highlight the correlations between DM2 and neurodegenerative diseases. Experimental studies increasingly bring DM2 induction models as a possibility not only to better understand the endocrine and metabolic changes resulting from DM2, but also to investigate whether these same changes are capable of triggering characteristics similar to neurodegeneration. This provides a new research possibility for neurodegenerative diseases. It brings further clarification about environmental factors, such as the modern lifestyle, about the emergence of diseases such as DM2 and its association with neurodegenerative diseases, such as AD and PD (Figure 6). 
Figure 6. It appears that insulin plays a central role in the neurodegeneration process, because other factors such as increased oxidative stress, increased AGES production and exacerbated inflammation are triggered by it.

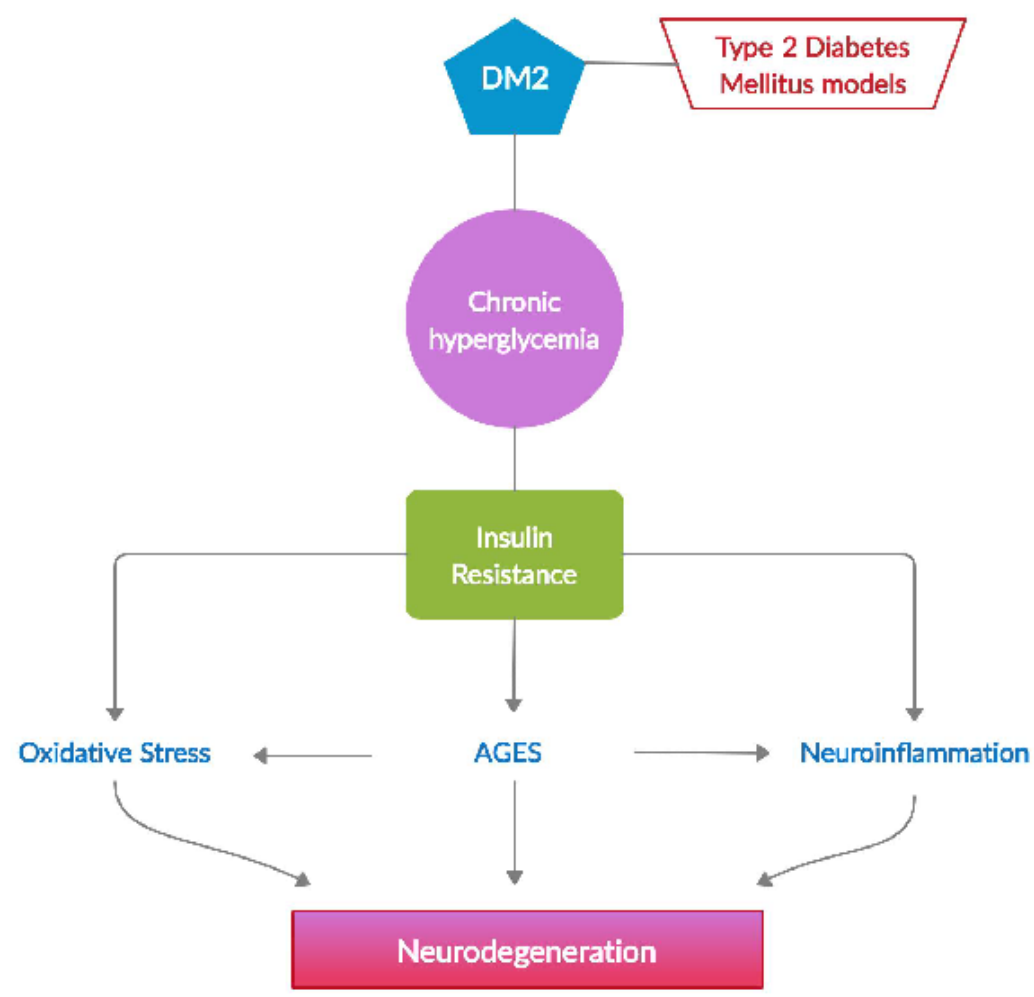

Source: Authors

Further studies are needed to better understand the mechanisms that involve DM2 and the neurodegeneration processes. Since insulin resistance seems to be the main link between these pathologies, it is extremely important to develop research that evaluates the role of resistance to this hormone as a factor that contributes to the emergence of neurodegenerative diseases. Thus, there will be a better clarification of these mechanisms that involve these different pathologies providing possible improvements in their treatments.

\section{References}

Ahmad, W., Ijaz, B., Shabbiri, K., Ahmed, F., \& Rehman, S. (2017). Oxidative toxicity in diabetes and Alzheimer's disease: Mechanisms behind ROS/ RNS generation. Journal of Biomedical Science, 24(1), 1-10. https://doi.org/10.1186/s12929-017-0379-z

Alberdi, E., Sánchez-Gómez, M. V., Cavaliere, F., Pérez-Samartín, A., Zugaza, J. L., Trullas, R., Domercq, M., \& Matute, C. (2010). Amyloid $\beta$ oligomers induce $\mathrm{Ca} 2+$ dysregulation and neuronal death through activation of ionotropic glutamate receptors. Cell Calcium, 47(3), 264-272. https://doi.org/10.1016/j.ceca.2009.12.010

Alfa, R. W., \& Kim, S. K. (2016). Using Drosophila to discover mechanisms underlying type 2 diabetes. DMM Disease Models and Mechanisms, 9(4), 365376. https://doi.org/10.1242/dmm.023887

Álvarez-Rendón, J. P., Salceda, R., \& Riesgo-Escovar, J. R. (2018). Drosophila melanogaster as a Model for Diabetes Type 2 Progression. BioMed Research International, 2018. https://doi.org/10.1155/2018/1417528

Alves, L., Correia, A. S. A., Miguel, R., Alegria, P., \& Bugalho, P. (2012). Alzheimer's disease: A clinical practice-oriented review. Frontiers in Neurology, APR(April), 1-20. https://doi.org/10.3389/fneur.2012.00063

Amorim, R. G., Guedes, G. da S., Vasconcelos, S. M. de L., \& Santos, J. C. de F. (2019). Kidney disease in diabetes mellitus: Cross-linking between hyperglycemia, redox imbalance and inflammation. Arquivos Brasileiros de Cardiologia, 112(5), 577-587. https://doi.org/10.5935/abc.20190077 
244. https://doi.org/10.23925/2176-901X.2010v13i1p

Arulmozhi, D. K., Veeranjaneyulu, A., \& Bodhankar, S. L. (2004). Neonatal streptozotocin-induced rat model of type 2 diabetes mellitus: A glance. Indian Journal of Pharmacology, 36(4), 217-221.

Athauda, D., \& Foltynie, T. (2016). Insulin resistance and Parkinson's disease: A new target for disease modification? Progress in Neurobiology, 145-146, 98-120. https://doi.org/10.1016/j.pneurobio.2016.10.001

Atkinson, B. J., Griesel, B. A., King, C. D., Josey, M. A., \& Olson, A. L. (2013). Moderate glut4 overexpression improves insulin sensitivity and fasting triglyceridemia in high-fat diet-fed transgenic mice. Diabetes, 62(7), 2249-2258. https://doi.org/10.2337/db12-1146

Baglietto-Vargas, D., Shi, J., Yaeger, D. M., Ager, R., \& LaFerla, F. M. (2016). Diabetes and Alzheimer's disease crosstalk. Neuroscience and Biobehavioral Reviews, 64, 272-287. https://doi.org/10.1016/j.neubiorev.2016.03.005

Baker, K. D., Loughman, A., Spencer, S. J., \& Reichelt, A. C. (2017). The impact of obesity and hypercaloric diet consumption on anxiety and emotional behavior across the lifespan. Neuroscience and Biobehavioral Reviews, 83, 173-182. https://doi.org/10.1016/j.neubiorev.2017.10.014

Balestrino, R., \& Schapira, A. H. V. (2020). Parkinson disease. European Journal of Neurology, 27(1), 27-42. https://doi.org/10.1111/ene.14108

Balsan, G. A., Da Costa Vieira, J. L., De Oliveira, A. M., \& Portal, V. L. (2015). Relationship between adiponectin, obesity and insulin resistance. In Revista da Associacao Medica Brasileira. https://doi.org/10.1590/1806-9282.61.01.072

Barbosa, L. F., De Medeiros, M. H. G., \& Augusto, O. (2006). Danos oxidativos e neurodegeneração: O quê aprendemos com animais transgênicos e nocautes? Quimica Nova, 29(6), 1352-1360. https://doi.org/10.1590/S0100-40422006000600034

Birse, R. T., Choi, J., Reardon, K., Rodriguez, J., Graham, S., Diop, S., Ocorr, K., Bodmer, R., \& Oldham, S. (2010). High-fat-diet-induced obesity and heart dysfunction are regulated by the TOR pathway in Drosophila. Cell Metabolism, 12(5), 533-544. https://doi.org/10.1016/j.cmet.2010.09.014

Bitel, C. L., Kasinathan, C., Kaswala, R. H., Klein, W. L., \& Frederikse, P. H. (2012). Amyloid- $\beta$ and tau pathology of Alzheimer's disease induced by diabetes in a RABBIT animal model. Journal of Alzheimer's Disease, 32(2), 291-305. https://doi.org/10.3233/JAD-2012-120571

Blázquez, E., Velázquez, E., Hurtado-Carneiro, V., \& Ruiz-Albusac, J. M. (2014). Insulin in the brain: Its pathophysiological implications for states related with central insulin resistance, type 2 diabetes and alzheimer's disease. Frontiers in Endocrinology, 5(OCT), 1-21. https://doi.org/10.3389/fendo.2014.00161

Braak, H., Del Tredici, K., Rüb, U., De Vos, R. A. I., Jansen Steur, E. N. H., \& Braak, E. (2003). Staging of brain pathology related to sporadic Parkinson's disease. Neurobiology of Aging, 24(2), 197-211. https://doi.org/10.1016/S0197-4580(02)00065-9

Brownlee, M. (2005). The pathobiology of diabetic complications: A unifying mechanism. Diabetes, 54(6), 1615-1625. https://doi.org/10.2337/diabetes.54.6.1615

Calle, M. C., \& Fernandez, M. L. (2012). Inflammation and type 2 diabetes. Diabetes and Metabolism, 38(3), 183-191. https://doi.org/10.1016/j.diabet.2011.11.006

Carvalho, E. N. de, Carvalho, N. A. S. de, \& Ferreira, L. M. (2003). Experimental model of induction of diabetes mellitus in rats. Acta Cirurgica Brasileira, 18(spe), 60-64. https://doi.org/10.1590/s0102-86502003001100009

Castellani, R. J., Peclovits, A., \& Perry, G. (2014). Neuropathology of Alzheimer's Disease. In Pathobiology of Human Disease: A Dynamic Encyclopedia of Disease Mechanisms. https://doi.org/10.1016/B978-0-12-386456-7.04604-9

Cheignon, C., Tomas, M., Bonnefont-Rousselot, D., Faller, P., Hureau, C., \& Collin, F. (2018). Oxidative stress and the amyloid beta peptide in Alzheimer's disease. Redox Biology, 14(October 2017), 450-464. https://doi.org/10.1016/j.redox.2017.10.014

Chen, K., Maley, J., \& Yu, P. H. (2006). Potential implications of endogenous aldehydes in $\beta$-amyloid misfolding, oligomerization and fibrillogenesis. Journal of Neurochemistry, 99(5), 1413-1424. https://doi.org/10.1111/j.1471-4159.2006.04181.x

Chico, L., Simoncini, C., Lo Gerfo, A., Rocchi, A., Petrozzi, L., Carlesi, C., Volpi, L., Tognoni, G., Siciliano, G., \& Bonuccelli, U. (2013). Oxidative stress and APO $\mathrm{e}$ polymorphisms in Alzheimer's disease and in mild cognitive impairment. Free Radical Research, 47(8), 569-576. https://doi.org/10.3109/10715762.2013.804622

Choi, Y. G., \& Lim, S. (2010). Ne\{open\}-(carboxymethyl)lysine linkage to $\alpha$-synuclein and involvement of advanced glycation end products in $\alpha$-synuclein deposits in an MPTP-intoxicated mouse model. Biochimie, 92(10), 1379-1386. https://doi.org/10.1016/j.biochi.2010.06.025

Choi, Y. H., Kwon, H. S., Shin, S. G., \& Chung, C. K. (2014). Vaccinium uliginosum L. improves amyloid $\beta$ protein-induced learning and memory impairment in Alzheimer's disease in mice. Preventive Nutrition and Food Science, 19(4), 343-347. https://doi.org/10.3746/pnf.2014.19.4.343

Cobb, C. A., \& Cole, M. P. (2015). Oxidative and nitrative stress in neurodegeneration. Neurobiology of Disease, 84, 4-21. https://doi.org/10.1016/j.nbd.2015.04.020

Cole, A. R., Astell, A., Green, C., \& Sutherland, C. (2007). Molecular connexions between dementia and diabetes. Neuroscience and Biobehavioral Reviews, 31(7), 1046-1063. https://doi.org/10.1016/j.neubiorev.2007.04.004

Comelli, F., Bettoni, I., Colleoni, M., Giagnoni, G., \& Costa, B. (2009). Beneficial effects of a Cannabis sativa extract treatment on diabetes-induced neuropathy and oxidative stress. Phytotherapy Research. https://doi.org/10.1002/ptr.2806

Compta, Y., Parkkinen, L., Kempster, P., Selikhova, M., Lashley, T., Holton, J. L., Lees, A. J., \& Revesz, T. (2014). The significance of $\alpha$-synuclein, amyloid$\beta$ and tau pathologies in parkinson's disease progression and related dementia. Neurodegenerative Diseases, 13(2-3), 154-156. https://doi.org/10.1159/000354670 
Côté, S., Carmichael, P. H., Verreault, R., Lindsay, J., Lefebvre, J., \& Laurin, D. (2012). Nonsteroidal anti-inflammatory drug use and the risk of cognitive impairment and Alzheimer's disease. Alzheimer's and Dementia, 8(3), 219-226. https://doi.org/10.1016/j.jalz.2011.03.012

Craft, S., Asthana, S., Cook, D. G., Baker, L. D., Cherrier, M., Purganan, K., Wait, C., Petrova, A., Latendresse, S., Watson, G. S., Newcomer, J. W., Schellenberg, G. D., \& Krohn, A. J. (2003). Insulin dose-response effects on memory and plasma amyloid precursor protein in Alzheimer's disease: Interactions with apolipoprotein E genotype. Psychoneuroendocrinology, 28(6), 809-822. https://doi.org/10.1016/S0306-4530(02)00087-2

Dalfó, E., Portero-Otín, M., Ayala, V., Martínez, A., Pamplona, R., \& Ferrer, I. (2005). Evidence of oxidative stress in the neocortex in incidental Lewy body disease. Journal of Neuropathology and Experimental Neurology, 64(9), 816-830. https://doi.org/10.1097/01.jnen.0000179050.54522.5

Damasceno, D. C., Volpato, G. T., De Mattos Paranhos Calderon, I., Aguilar, R., \& Rudge, M. V. C. (2004). Effect of Bauhinia forficata extract in diabetic pregnant rats: Maternal repercussions. Phytomedicine, 11(2-3), 196-201. https://doi.org/10.1078/0944-7113-00348

De Felice, F. G., \& Ferreira, S. T. (2014). Inflammation, defective insulin signaling, and mitochondrial dysfunction as common molecular denominators connecting type 2 diabetes to Alzheimer Disease. Diabetes, 63(7), 2262-2272. https://doi.org/10.2337/db13-1954

Delfino, V. D., Figueireso, J. F., Matsuo, T., Favero, maria E., \& Mocelin, A. M. M. e A. (2002). Streptozotocin-induced diabetes mellitus: long-term comparison of two drug administration routes. Brazilian Journal of Nephrology (Jornal Brasileiro de Nefrologia), 24(1), 31-36.

Dickson, D. W. (2018). Neuropathology of Parkinson disease. Parkinsonism and Related Disorders, 46, S30-S33. https://doi.org/10.1016/j.parkreldis.2017.07.033

Dineley, K. T., Jahrling, J. B., \& Denner, L. (2014). Insulin resistance in Alzheimer's disease. Neurobiology of Disease, 72(Part A), 92-103. https://doi.org/10.1016/j.nbd.2014.09.001

Donath, M. Y., \& Shoelson, S. E. (2011). Type 2 diabetes as an inflammatory disease. Nature Reviews Immunology, 11(2), 98-107. https://doi.org/10.1038/nri2925

Duka, T., Duka, V., Joyce, J. N., \& Sidhu, A. (2009). $\alpha$-Synuclein contributes to GSK-3 $\beta$-catalyzed Tau phosphorylation in Parkinson's disease models. The FASEB Journal, 23(9), 2820-2830. https://doi.org/10.1096/fj.08-120410

Faure, P., Troncy, L., Lecomte, M., Wiernsperger, N., Lagarde, M., Ruggiero, D., \& Halimi, S. (2005). Albumin antioxidant capacity is modified by methylglyoxal. Diabetes and Metabolism, 31(2), 169-177. https://doi.org/10.1016/S1262-3636(07)70183-0

Ferreira, L. M., \& Ferreira, L. R. K. (2003). Experimental model: historic and conceptual revision. Acta Cirurgica Brasileira, 18(spe), 01-03. https://doi.org/10.1590/s0102-86502003001100001

Ferreira, L. M., Hochman, B., \& Barbosa, M. V. J. (2005). Modelos experimentais em pesquisa. Acta Cirurgica Brasileira, 20(SUPPL. 2), 28-34. https://doi.org/10.1590/s0102-86502005000800008

Fisher, T. L., \& White, M. F. (2004). Signaling pathways: The benefits of good communication. Current Biology, 14(23), 1005-1007. https://doi.org/10.1016/j.cub.2004.11.024

Flor, L. S., \& Campos, M. R. (2017). Prevalência de diabetes mellitus e fatores associados na população adulta brasileira: Evidências de um inquérito de base populacional. Revista Brasileira de Epidemiologia, 20(1), 16-29. https://doi.org/10.1590/1980-5497201700010002

Folmer, V., Soares, J. C. M., \& Rocha, J. B. T. (2002). Oxidative stress in mice is dependent on the free glucose content of the diet. International Journal of Biochemistry and Cell Biology, 34(10), 1279-1285. https://doi.org/10.1016/S1357-2725(02)00065-1

Francés, D. E., Ingaramo, P. I., Ronco, M. T., \& Carnovale, C. E. (2013). Diabetes, an inflammatory process: Oxidative Stress and TNF-alpha involved in hepatic complication. Journal of Biomedical Science and Engineering, 06(06), 645-653. https://doi.org/10.4236/jbise.2013.66079

Furman, B. L. (2015). Streptozotocin-Induced Diabetic Models in Mice and Rats. Current Protocols in Pharmacology. https://doi.org/10.1002/0471141755.ph0547s70

Gao, X., Chen, H., Fung, T. T., Logroscino, G., Schwarzschild, M. A., Hu, F. B., \& Ascherio, A. (2007). Prospective study of dietary pattern and risk of Parkinson disease. American Journal of Clinical Nutrition, 86(5), 1486-1494. https://doi.org/10.1093/ajcn/86.5.1486

Gejl, M., Brock, B., Egefjord, L., Vang, K., Rungby, J., \& Gjedde, A. (2017). Blood-Brain Glucose Transfer in Alzheimer's disease: Effect of GLP-1 Analog Treatment. Scientific Reports, 7(1), 1-10. https://doi.org/10.1038/s41598-017-17718-y

Ghasemi, R., Haeri, A., Dargahi, L., Mohamed, Z., \& Ahmadiani, A. (2013). Insulin in the brain: Sources, localization and functions. Molecular Neurobiology, 47(1), 145-171. https://doi.org/10.1007/s12035-012-8339-9

Giacco, F., \& Brownlee, M. (2010). Oxidative stress and diabetic complications. Circulation Research, 107(9), 1058-1070. https://doi.org/10.1161/CIRCRESAHA.110.223545

Gil, A. C. (2002). Como elaborar projetos de pesquisa http://www.uece.br/nucleodelinguasitaperi/dmdocuments/gil_como_elaborar_projeto_de_pesquisa.pdf

Gottlieb, M. (2010). Estresse oxidativo como fator de risco cardiometabólico emergente Oxidative stress as an emergent cardiometabolic risk factor. Scientia Medica, 20(3), 243-249.

Gray, S. M., Meijer, R. I., \& Barrett, E. J. (2014). Insulin regulates brain function, but how does it get there? Diabetes, 63(12), 3992-3997. https://doi.org/10.2337/db14-0340 
Gudala, K., Bansal, D., Schifano, F., \& Bhansali, A. (2013). Diabetes mellitus and risk of dementia: A meta-analysis of prospective observational studies. Journal of Diabetes Investigation, 4(6), 640-650. https://doi.org/10.1111/jdi.12087

Hardas, S. S., Sultana, R., Clark, A. M., Beckett, T. L., Szweda, L. I., Paul Murphy, M., \& Butterfield, D. A. (2013). Oxidative modification of lipoic acid by HNE in alzheimer disease brain. Redox Biology, 1(1), 80-85. https://doi.org/10.1016/j.redox.2013.01.002

He, Y., Thong, P. S., Lee, T., Leong, S. K., Mao, B. Y., Dong, F., \& Watt, F. (2003). Dopaminergic cell death precedes iron elevation in MPTP-injected monkeys. Free Radical Biology and Medicine, 35(5), 540-547. https://doi.org/10.1016/S0891-5849(03)00385-X

Heydemann, A. (2016). An Overview of Murine High Fat Diet as a Model for Type 2 Diabetes Mellitus. Journal of Diabetes Research, 2016. https://doi.org/10.1155/2016/2902351

Hochman, B., Ferreira, L. M., Bôas, F. C. V., \& Mariano, M. (2004). Experimental model in hamster (Mesocricetus auratus) to study heterologous graft of scars and cutaneous diseases in plastic surgery. Acta Cirurgica Brasileira, 19(suppl 1), 69-78. https://doi.org/10.1590/s0102-86502004000700013

Holtzman, D. M., Morris, J. C., \& Goate, A. M. (2011). Science Translational Medicine Volume 3 issue 772011 [doi 10.1126\%2Fscitranslmed.3002369] Holtzman, D. M.; Morris, J. C.; Goate, A. M. -- Alzheimer's Disease- The Challenge of the Second Century.pdf. 3(77).

Irwin, D. J., Lee, V. M. Y., \& Trojanowski, J. Q. (2013). Parkinson's disease dementia: Convergence of $\alpha$-synuclein, tau and amyloid- $\beta$ pathologies. Nature Reviews Neuroscience, 14(9), 626-636. https://doi.org/10.1038/nrn3549

Iser, B. P. M., Stopa, S. R., Chueiri, P. S., Szwarcwald, C. L., Malta, D. C., Monteiro, H. O. da C., Duncan, B. B., \& Schmidt, M. I. (2015). Prevalência de diabetes autorreferido no Brasil: resultados da Pesquisa Nacional de Saúde 2013. Epidemiologia e Serviços de Saúde, 24(2), 305-314. https://doi.org/10.5123/s1679-49742015000200013

Kandimalla, R., Thirumala, V., \& Reddy, P. H. (2017). Is Alzheimer's disease a Type 3 Diabetes? A critical appraisal. Biochimica et Biophysica Acta Molecular Basis of Disease, 1863(5), 1078-1089. https://doi.org/10.1016/j.bbadis.2016.08.018

Kang, Y. E., Kim, J. M., Joung, K. H., Lee, J. H., You, B. R., Choi, M. J., Ryu, M. J., Ko, Y. B., Lee, M. A., Lee, J., Ku, B. J., Shong, M., Lee, K. H., \& Kim, H. J. (2016). The roles of adipokines, proinflammatory cytokines, and adipose tissue macrophages in obesity-associated insulin resistance in modest obesity and early metabolic dysfunction. PLOS ONE, 11(4), 1-14. https://doi.org/10.1371/journal.pone.0154003

Khasnavis, S., Jana, A., Roy, A., Mazumder, M., Bhushan, B., Wood, T., Ghosh, S., Watson, R., \& Pahan, K. (2012). Suppression of nuclear factor-кB activation and inflammation in microglia by physically modified saline. Journal of Biological Chemistry, 287(35), 29529-29542. https://doi.org/10.1074/jbc.M111.338012

Ko, S. Y., Lin, Y. P., Lin, Y. S., \& Chang, S. S. (2010). Advanced glycation end products enhance amyloid precursor protein expression by inducing reactive oxygen species. Free Radical Biology and Medicine, 49(3), 474-480. https://doi.org/10.1016/j.freeradbiomed.2010.05.005

Koehler, N. K. U., Stransky, E., Shing, M., Gaertner, S., Meyer, M., Schreitmüller, B., Leyhe, T., Laske, C., Maetzler, W., Kahle, P., Celej, M. S., Jovin, T. M., Fallgatter, A. J., Batra, A., Buchkremer, G., Schott, K., \& Richartz-Salzburger, E. (2013). Altered Serum IgG Levels to $\alpha-S y n u c l e i n$ in Dementia with Lewy Bodies and Alzheimer's Disease. PLoS ONE, 8(5), 1-7. https://doi.org/10.1371/journal.pone.0064649

Lee, D., Park, C. W., Paik, S. R., \& Choi, K. Y. (2009). The modification of $\alpha$-synuclein by dicarbonyl compounds inhibits its fibril-forming process. Biochimica et Biophysica Acta - Proteins and Proteomics, 1794(3), 421-430. https://doi.org/10.1016/j.bbapap.2008.11.016

Letra, L., Santana, I., \& Seiça, R. (2014). Obesity as a risk factor for Alzheimer's disease: the role of adipocytokines. Metabolic Brain Disease, 29(3), 563568. https://doi.org/10.1007/s11011-014-9501-z

Li, J., Liu, D., Sun, L., Lu, Y., \& Zhang, Z. (2012). Advanced glycation end products and neurodegenerative diseases: Mechanisms and perspective. Journal of the Neurological Sciences, 317(1-2), 1-5. https://doi.org/10.1016/j.jns.2012.02.018

Li, X., Song, D., \& Leng, S. X. (2015). Link between type 2 diabetes and Alzheimer's disease: From epidemiology to mechanism and treatment. Clinical Interventions in Aging, 10, 549-560. https://doi.org/10.2147/CIA.S74042

Lizcano, J. M., \& Alessi, D. R. (2002). The insulin signalling pathway. Current Biology, 12(7), 236-238. https://doi.org/10.1016/S0960-9822(02)00777-7

Macauley-Rambach, S., Stanley, M., Yamada, S., Caesar, E., Raichle, M., Perez, R., Mahan, T., \& Holtzman, D. (2015). Hyperglycemia modulates extracellular amyloid-beta levels and neuronal activity in vivo. Neurodegenerative Diseases, 15, 570. https://doi.org/10.1172/JCI79742DS1

Maciejczyk, M., Żebrowska, E., \& Chabowski, A. (2019). Insulin resistance and oxidative stress in the brain: What's new? International Journal of Molecular Sciences, 20(4). https://doi.org/10.3390/ijms20040874

Mandrekar-Colucci, S., \& Landreth, G. E. (2012). Microglia and Inflammation in Alzheimers Disease. CNS \& Neurological Disorders - Drug Targets. https://doi.org/10.2174/187152710791012071

Marques-Lopes, I., Marti, A., Moreno-Aliaga, M. J., \& Martínez, A. (2004). Aspectos genéticos da obesidade. Revista de Nutricao, 17(3), 327-338. https://doi.org/10.1590/s1415-52732004000300006

Mattsson, N., Insel, P., Tosun, D., Zhang, J., Jack, C. R., Galasko, D., \& Weiner, M. (2013). Effects of baseline CSF $\alpha$-synuclein on regional brain atrophy rates in healthy elders, mild cognitive impairment and Alzheimer's disease. PLoS ONE, 8(12), 1-9. https://doi.org/10.1371/journal.pone.0085443

Mochizuki, H., \& Yasuda, T. (2012). Iron accumulation in Parkinson's disease. Journal of Neural Transmission, 119(12), 1511-1514. https://doi.org/10.1007/s00702-012-0905-9

Montufar, S., Calero, C., Vinueza, R., Correa, P., Carrera-Gonzalez, A., Villegas, F., Moreta, G., \& Paredes, R. (2017). Association between the APOE $€ 4$ Allele and Late-Onset Alzheimer's Disease in an Ecuadorian Mestizo Population. International Journal of Alzheimer's Disease. 
https://doi.org/10.1155/2017/1059678

Morita, M., Ikeshima-Kataoka, H., Kreft, M., Vardjan, N., Zorec, R., \& Noda, M. (2019). Metabolic plasticity of astrocytes and aging of the brain. In International Journal of Molecular Sciences. https://doi.org/10.3390/ijms20040941

Morris, J. K., Bomhoff, G. L., Stanford, J. A., \& Geiger, P. C. (2010). Neurodegeneration in an animal model of Parkinson's disease is exacerbated by a highfat diet. American Journal of Physiology - Regulatory Integrative and Comparative Physiology, 299(4), 1-3. https://doi.org/10.1152/ajpregu.00449.2010

Morris, S. N. S., Coogan, C., Chamseddin, K., Fernandez-Kim, S. O., Kolli, S., Keller, J. N., \& Bauer, J. H. (2012). Development of diet-induced insulin resistance in adult Drosophila melanogaster. Biochimica et Biophysica Acta - Molecular Basis of Disease. https://doi.org/10.1016/j.bbadis.2012.04.012

Münzberg, H., \& Myers, M. G. (2005). Molecular and anatomical determinants of central leptin resistance. Nature Neuroscience, 8(5), 566-570. https://doi.org/10.1038/nn1454

Murphy, M. P., \& Levine, H. (2010). Alzheimer's Disease and the Beta-Amyloid Peptide. Journal of Alzheimer's Disease, 19(1), 1-17. https://doi.org/10.3233/JAD-2010-1221.Alzheimer

Nandi, A., Kitamura, Y., Kahn, C. R., \& Accili, D. (2004). Mouse Models of Insulin Resistance. Physiological Reviews, 84(2), 623-647. https://doi.org/10.1152/physrev.00032.2003

Nelson, P. T., \& Schmitt, F. A. (2011). Age Number One Factor of Alzheimer'S Disease. Acta Neuropathol, 121(5), 571-587. https://doi.org/10.1007/s00401011-0826-y.Alzheimer

Niedowicz, D. M., \& Daleke, D. L. (2005). The role of oxidative stress in diabetic complications. Cell Biochemistry and Biophysics, 43(2), 289-330. https://doi.org/10.1385/CBB:43:2:289

Nowotny, K., Jung, T., Höhn, A., Weber, D., \& Grune, T. (2015). Advanced glycation end products and oxidative stress in type 2 diabetes mellitus. Biomolecules, 5(1), 194-222. https://doi.org/10.3390/biom5010194

Pardeshi, R., Bolshette, N., Gadhave, K., Ahire, A., Ahmed, S., Cassano, T., Gupta, V. B., \& Lahkar, M. (2017). Insulin signaling: An opportunistic target to minify risk of Alzheimer's disease. Psychoneuroendocrinology, 83, 159-171. https://doi.org/10.1016/j.psyneuen.2017.05.004

Park, S., Alfa, R. W., Topper, S. M., Kim, G. E. S., Kockel, L., \& Kim, S. K. (2014). A Genetic Strategy to Measure Circulating Drosophila Insulin Reveals Genes Regulating Insulin Production and Secretion. PLoS Genetics. https://doi.org/10.1371/journal.pgen.1004555

Pereira, A. S., Shitsuka, D. M., Parreira, F. J., \& Shitsuka, R. (2018). Método Qualitativo, Quantitativo ou Quali-Quanti. In Metodologia da Pesquisa Científica. https://repositorio.ufsm.br/bitstream/handle/1/15824/Lic_Computacao_Metodologia-Pesquisa-Cientifica.pdf?sequence=1.

Perfeito, R., Cunha-Oliveira, T., \& Rego, A. C. (2012). Revisiting oxidative stress and mitochondrial dysfunction in the pathogenesis of Parkinson disease Resemblance to the effect of amphetamine drugs of abuse. Free Radical Biology and Medicine, 53(9), 1791-1806. https://doi.org/10.1016/j.freeradbiomed.2012.08.569

Perrotta, F., Nigro, E., Mollica, M., Costigliola, A., D’agnano, V., Daniele, A., Bianco, A., \& Guerra, G. (2019). Pulmonary hypertension and obesity: Focus on adiponectin. In International Journal of Molecular Sciences. https://doi.org/10.3390/ijms20040912

Pham, J. D., Chim, N., Goulding, C. W., \& Nowick, J. S. (2013). Structures of oligomers of a peptide from $\beta$-amyloid. Journal of the American Chemical Society, 135(33), 12460-12467. https://doi.org/10.1021/ja4068854

Pisoschi, A. M., \& Pop, A. (2015). The role of antioxidants in the chemistry of oxidative stress: A review. European Journal of Medicinal Chemistry, 97, 5574. https://doi.org/10.1016/j.ejmech.2015.04.040

Pitocco, D., Zaccardi, F., Di Stasio, E., Romitelli, F., Santini, S. A., Zuppi, C., \& Ghirlanda, G. (2010). Oxidative stress, nitric oxide, and diabetes. Review of Diabetic Studies, 7(1), 15-25. https://doi.org/10.1900/RDS.2010.7.15

Poewe, W., Seppi, K., Tanner, C. M., Halliday, G. M., Brundin, P., Volkmann, J., Schrag, A. E., \& Lang, A. E. (2017). Parkinson disease. Nature Reviews Disease Primers, 3, 1-21. https://doi.org/10.1038/nrdp.2017.13

Poirier, J., Miron, J., Picard, C., Gormley, P., Théroux, L., Breitner, J., \& Dea, D. (2014). Apolipoprotein E and lipid homeostasis in the etiology and treatment of sporadic Alzheimer's disease. Neurobiology of Aging, 35(SUPPL.2), S3-S10. https://doi.org/10.1016/j.neurobiolaging.2014.03.037

Prado, I. O. do, Goulart, A. da S., Viçosa, D. L., Folmer, V., \& Salgueiro, A. C. F. (2020). Efeitos metabólicos da infusão das folhas de Bauhinia forficata em Drosophila melanogaster alimentadas com uma dieta rica em sacarose. Research, Society and Development. https://doi.org/10.33448/rsd-v9i3.2377

Prince, M., Bryce, R., Albanese, E., Wimo, A., Ribeiro, W., \& Ferri, C. P. (2013). The global prevalence of dementia: A systematic review and metaanalysis. Alzheimer's and Dementia, 9(1), 63-75.e2. https://doi.org/10.1016/j.jalz.2012.11.007

Pringsheim, T., Jette, N., Frolkis, A., \& Steeves, T. D. L. (2014). The prevalence of Parkinson's disease: A systematic review and meta-analysis. Movement Disorders, 29(13), 1583-1590. https://doi.org/10.1002/mds.25945

Radi, E., Formichi, P., Battisti, C., \& Federico, A. (2014). Apoptosis and oxidative stress in neurodegenerative diseases. Journal of Alzheimer's Disease, 42, S125-S152. https://doi.org/10.3233/JAD-132738

Ramkumar, K. M., Vanitha, P., Uma, C., Suganya, N., Bhakkiyalakshmi, E., \& Sujatha, J. (2011). Antidiabetic activity of alcoholic stem extract of Gymnema montanum in streptozotocin-induced diabetic rats. Food and Chemical Toxicology, 49(12), 3390-3394. https://doi.org/10.1016/j.fct.2011.09.027

Reagan, L. P. (2012). Diabetes as a chronic metabolic stressor: Causes, consequences and clinical complications. Experimental Neurology, 233(1), 68-78. https://doi.org/10.1016/j.expneurol.2011.02.004 
Reddy, P. H. (2011). Abnormal tau, mitochondrial dysfunction, impaired axonal transport of mitochondria, and synaptic deprivation in Alzheimer's disease. Brain Research, 1415, 136-148. https://doi.org/10.1016/j.brainres.2011.07.052

Rees, K., Stowe, R., Patel, S., Ives, N., Breen, K., Ben-Shlomo, Y., \& Clarke, C. E. (2011). Anti-hypertensive drugs as disease-modifying agents for Parkinson's disease: evidence from observational studies and clinical trials. Cochrane Database of Systematic Reviews. https://doi.org/10.1002/14651858.cd008535.pub2

Ribeiro Cesaretti, M. L., \& Kohlmann, O. (2006). Modelos experimentais de resistência à insulina e obesidade: Lições aprendidas. Arquivos Brasileiros de Endocrinologia e Metabologia, 50(2), 190-197. https://doi.org/10.1590/S0004-27302006000200005

Rohilla, A., \& Ali, S. (2012). Alloxan Induced Diabetes: Mechanisms and Effects. International Journal of Research in Pharmaceutical and Biomedical Science.

Salgueiro, A. C. F., Leal, C. Q., Bianchini, M. C., Prado, I. O., Mendez, A. S. L., Puntel, R. L., Folmer, V., Soares, F. A., Ávila, D. S., \& Puntel, G. O. (2013). The influence of Bauhinia forficata Link subsp. pruinosa tea on lipid peroxidation and non-protein SH groups in human erythrocytes exposed to high glucose concentrations. Journal of Ethnopharmacology, 148(1), 81-87. https://doi.org/10.1016/j.jep.2013.03.070

Salgueiro, Andréia Caroline Fernandes, Folmer, V., Da Silva, M. P., Mendez, A. S. L., Zemolin, A. P. P., Posser, T., Franco, J. L., Puntel, R. L., \& Puntel, G. O. (2016). Effects of Bauhinia forficata tea on oxidative stress and liver damage in diabetic mice. Oxidative Medicine and Cellular Longevity, 2016. https://doi.org/10.1155/2016/8902954

Sato, T., Shimogaito, N., Wu, X., Kikuchi, S., Yamagishi, S. I., \& Takeuchi, M. (2006). Toxic advanced glycation end products (TAGE) theory in Alzheimer's disease. American Journal of Alzheimer's Disease and Other Dementias, 21(3), 197-208. https://doi.org/10.1177/1533317506289277

Schernhammer, E., Hansen, J., Rugbjerg, K., Wermuth, L., \& Ritz, B. (2011). Diabetes and the risk of developing Parkinson's disease in Denmark. Diabetes Care, 34(5), 1102-1108. https://doi.org/10.2337/dc10-1333

Schildknecht, S., Gerding, H. R., Karreman, C., Drescher, M., Lashuel, H. A., Outeiro, T. F., Di Monte, D. A., \& Leist, M. (2013). Oxidative and nitrative alpha-synuclein modifications and proteostatic stress: Implications for disease mechanisms and interventions in synucleinopathies. Journal of Neurochemistry, 125(4), 491-511. https://doi.org/10.1111/jnc.12226

Seino, Y., Nanjo, K., Tajima, N., Kadowaki, T., Kashiwagi, A., Araki, E., Ito, C., Inagaki, N., Iwamoto, Y., Kasuga, M., Hanafusa, T., Haneda, M., \& Ueki, K. (2010). Report of the Committee on the classification and diagnostic criteria of diabetes mellitus: The Committee of the Japan Diabetes Society on the diagnostic criteria of diabetes mellitus. Diabetology International, 1(1), 2-20. https://doi.org/10.1007/s13340-010-0006-7

Sekiyama, K., Sugama, S., Fujita, M., Sekigawa, A., Takamatsu, Y., Waragai, M., Takenouchi, T., \& Hashimoto, M. (2012). Neuroinflammation in Parkinson's disease and related disorders: A lesson from genetically manipulated mouse models of $\alpha$-synucleinopathies. Parkinson's Disease, 2012. https://doi.org/10.1155/2012/271732

Silva, M., de Lima, W. G., \& Pedrosa, M. E. S. L. (2011). Efeito da estreptozotocina sobre os perfis glicêmico e lipídico e o estresse oxidativo em hamsters. Arquivos Brasileiros de Endocrinologia e Metabologia, 55(1), 46-53. https://doi.org/10.1590/S0004-27302011000100006

Sims-robinson, C., Kim, B., Rosko, A., \& Feldman, E. L. (2011). 1-19 diabetes accelerate Alzheimer disease pathology. 6(10), 551-559. https://doi.org/10.1038/nrneurol.2010.130.How

Srinivasan, K., \& Ramarao, P. (2012). Animal models in type 2 diabetes research: An overview K. Indian Journal of Medical Research, 136(1), 451-472.

Sun, X., Jin, L., Ling, P., \& Ling, P. (2011). Review of drugs for Alzheimer's disease. Drug Discoveries \& Therapeutics, 6(6), 285-290. https://doi.org/10.5582/ddt.2012.v6.6.285

Szablewski, L. (2017). Glucose Transporters in Brain: In Health and in Alzheimer's Disease. Journal of Alzheimer's Disease, 55(4), 1307-1320. https://doi.org/10.3233/JAD-160841

Timper, K., \& Donath, M. Y. (2012). Diabetes mellitus Type 2 - The new face of an old lady. Swiss Medical Weekly, 142(JULY). https://doi.org/10.4414/smw.2012.13635

Tsang, A. H. K., \& Chung, K. K. K. (2009). Oxidative and nitrosative stress in Parkinson's disease. Biochimica et Biophysica Acta - Molecular Basis of Disease, 1792(7), 643-650. https://doi.org/10.1016/j.bbadis.2008.12.006

Tumminia, A., Vinciguerra, F., Parisi, M., \& Frittitta, L. (2018). Type 2 diabetes mellitus and alzheimer's disease: Role of insulin signalling and therapeutic implications. International Journal of Molecular Sciences, 19(11). https://doi.org/10.3390/ijms19113306

Tuon, T. (2012). O papel do estresse oxidativo e do exercício físico na doença de Parkinson. Revista Brasileira de Fisiologia Do Exercício, 11 (3), 174. https://doi.org/10.33233/rbfe.v11i3.3403

Vicente Miranda, H., El-Agnaf, O. M. A., \& Outeiro, T. F. (2016). Glycation in Parkinson's disease and Alzheimer's disease. Movement Disorders, 31(6), 782-790. https://doi.org/10.1002/mds.26566

Wang, L., Zhang, X. T., Zhang, H. Y., Yao, H. Y., \& Zhang, H. (2010). Effect of Vaccinium bracteatum Thunb. leaves extract on blood glucose and plasma lipid levels in streptozotocin-induced diabetic mice. Journal of Ethnopharmacology, 130(3), 465-469. https://doi.org/10.1016/j.jep.2010.05.031

White, P. A. S., Cercato, L. M., Araújo, J. M. D., Souza, L. A., Soares, A. F., Barbosa, A. P. O., Neto, J. M. d. R., Marçal, A. C., Machado, U. F., Camargo, E. A., Santos, M. R. V., \& Brito, L. C. (2013). Modelo de obesidade induzida por dieta hiperlipídica e associada à resistência à ação da insulina e intolerância à glicose. Arquivos Brasileiros de Endocrinologia e Metabologia, 57(5), 339-345. https://doi.org/10.1590/S0004-27302013000500002

Wolkow, C. A., Muñoz, M. J., Riddle, D. L., \& Ruvkun, G. (2002). Insulin receptor substrate and p55 orthologous adaptor proteins function in the 
Research, Society and Development, v. 10, n. 1, e23410111673, 2021

(CC BY 4.0) | ISSN 2525-3409 | DOI: http://dx.doi.org/10.33448/rsd-v10i1.11673

Caenorhabditis elegans daf-2/insulin-like signaling pathway. Journal of Biological Chemistry. https://doi.org/10.1074/jbc.M207866200

Woltjer, R. L., Maezawa, I., Ou, J. J., Montine, K. S., \& Montine, T. J. (2003). Advanced glycation endproduct precursor alters intracellular amyloid- $\beta / A \beta P P$ carboxy-terminal fragment aggregation and cytotoxicity. Journal of Alzheimer's Disease, 5(6), 467-476. https://doi.org/10.3233/jad-2003-5607

Zhao, W., De Felice, F. G., Fernandez, S., Chen, H., Lambert, M. P., Quon, M. J., Krafft, G. A., \& Klein, W. L. (2008). Amyloid beta oligomers induce impairment of neuronal insulin receptors. The FASEB Journal, 22(1), 246-260. https://doi.org/10.1096/fj.06-7703com 